\title{
Spatial Analysis of Heavy Metal Emissions in Residential, Commercial and Industrial Areas Adjacent to a Scrap Metal Shredder in Winnipeg, Canada
}

\author{
Folarin Solademi, Shirley Thompson \\ Natural Resources Institute, University of Manitoba, Winnipeg, Canada \\ Email: s.thompson@umanitoba.ca
}

How to cite this paper: Solademi, F., \& Thompson, S. (2020). Spatial Analysis of Heavy Metal Emissions in Residential, Commercial and Industrial Areas Adjacent to a Scrap Metal Shredder in Winnipeg, Canada. Journal of Geoscience and Environment Protection, 8, 359-386.

https://doi.org/10.4236/gep.2020.85023

Received: February 26, 2020

Accepted: May 26, 2020

Published: May 29, 2020

Copyright $\odot 2020$ by author(s) and Scientific Research Publishing Inc. This work is licensed under the Creative Commons Attribution International License (CC BY 4.0).

http://creativecommons.org/licenses/by/4.0/

\begin{abstract}
A spatial analysis of air pollution in the South St. Boniface (SSB) and Mission Industrial Areas (MIA) of Winnipeg, in Manitoba, Canada, was conducted by mapping the results for 23 composite snow samples. Heavy metals were analyzed in the snow samples by Inductively Coupled Plasma Mass Spectrometry (ICP-MS). Higher concentrations closer to the shredder were significant for every metal, but, not for arsenic, in regression modeling $\mathrm{R}$ squared $(0.585$ for $\mathrm{Cd}, 0.462$ for $\mathrm{Pb}, 0.423$ for $\mathrm{Zn}, 0.343$ for $\mathrm{Cr}, 0.343$ for $\mathrm{Ni}, 0.244$ for $\mathrm{Mn}$, and 0.069 for As). Heavy metal concentrations were significantly higher in the industrial zone, with the next highest being the roadside zone, then the commercial zone and finally the residential/parkland zone, at $\mathrm{p}$-value $<0.01$ statistical significance levels according to the non-parametric Kruskal-Wallis $\mathrm{H}$ test. The metals concentrations mapped on Arc-GIS with ArcMap 10.6 using kriging interpolation, display that all toxic metal concentrations, but particularly $\mathrm{Pb}, \mathrm{Ni}, \mathrm{Zn}, \mathrm{Cr}$, and $\mathrm{Hg}$, are highest proximate to the scrap metal shredder. Furthermore, pollution indices, specifically contamination factor (CF), degree of contamination (DOC), and pollution load index (PLI), were undertaken registering high contamination. The $\mathrm{CF}$ registered high for lead, zinc, and nickel in all areas compared to the background levels, but the highest levels were nearby to the scrap metal shredder. The DOC values showed that the industrial contamination is nearly five times greater than that for the road or commercial areas and almost 20 times more contaminated compared to the residential/parkland. With PLI levels above 1 considered contaminated, the shredder (4.1), roadside (2.2), and commercial areas (1.9) were polluted. These
\end{abstract}


findings point to the shredder as the cause of present-day contamination for all areas, including residential/parkland, traffic, and commercial areas. High levels of toxic metal air pollution emissions warrant further study of human exposure and health risk posed by multiple sources from the air, water, and land. Enforcement and enclosure of the outdoor shredder should be considered to reduce heavy metal exposure to the public.

\section{Keywords}

Air Pollution, Heavy Metals, Particulate Matter, Pollution Indices, Maps, Snow, Spatial Analysis

\section{Introduction}

Recycling scrap metals from end-of-life vehicles (ELV) and other obsolete metallic products, compared to smelting virgin ore, uses less energy, produces less greenhouse gases and conserves natural resources (Wernick, \& Themelis, 1998; USEPA, 2009). On the other hand, the process of recycling scrap metal causes negative environmental and health impacts (OSHA, 2008; Salas-Luevano \& Vega-Carrillo, 2016). Recycling scrap metals pollutes (OSHA, 2008; USEPA, 2009) sometimes at levels exceeding the World Health Organization's guidelines for particulate matter and heavy metals (Loren et al., 2013; Owoade et al., 2015). To quantify and spatially analyze emissions from scrap metal recycling in South St. Boniface and Mission Industrial Areas of Winnipeg, Manitoba in Canada, this study measured heavy metals in snow to determine present-day pollution levels.

Heavy metals in scrap metal are released, as particulate and fumes, as well as in the recycled product and waste due to their use in many goods (Tchounwou et al., 2012; WHO, 2019a). Lead (Pb) is a component of many pipes, lead-acid batteries, leaded-steel components, cast-metal parts, and lead-based coatings. Mercury is a component in switches, thermometers, and gauges in electrical appliances (OSHA, 2008; WHO, 2019a). Nickel (Ni) is an ingredient of nickel-based alloy, aluminum-alloy, stainless steel (OSHA, 2008), as well as nickel-cadmium batteries, which also includes cadmium (Cd). As well as these batteries, cadmium comes from scrap metals coated with cadmium paint. Zinc $(\mathrm{Zn})$ is contained in scrap brass galvanized residues, zinc sheet, and $0.4 \%$ to $4.3 \%$ of tires (Smolders \& Degryse, 2002; OSHA, 2008). Arsenic (As) is present in nonferrous metals alloys, semiconductors in electronics, and hexavalent chromium from the creation of stainless and alloy steels from chromium (Cr) and improvement of anticorrosive properties (OSHA, 2008).

Short- and long-term exposures to these metals are capable of inducing carcinogenic, non-carcinogenic, and neurotoxic effects and the development of diseases in humans (Agency for Toxic Substance and Disease Registry (ATSDR, 2017). Arsenic, cadmium, chromium (including hexavalent chromium), and 
nickel are known to be human carcinogens, categorized as group 1, and inorganic lead is a possible human carcinogen (IARC, 2020). Also, lead is a teratogen and a neurotoxin. Children are very vulnerable to adverse health effects, affecting the development of the nervous system and brain (ATSDR, 2017; Olawoyin et al., 2018). Toxic metal pollution contaminates soil, water, snow, and air, thereby degrading these media and causing potential exposure pathways for humans and wildlife. As a result, the measurement of environmental media provides a basis to determine the ecological and human health risk posed by toxic heavy metals (Siudek et al., 2015; Li et al., 2016).

Scrap metal recycling and scrap iron smelting emit fine particulate matter $\left(\mathrm{PM}_{\leq 2.5}\right)$, and larger particulates into the ambient air (Owoade et al., 2015; Ogundele et al., 2016). Inhalation of the fine particles poses greater human health risks due to their ability to deposit in the respiratory airways and penetrate deeper into the lungs, thereby entering the bloodstream (Brown et al., 2013; USEPA, 2018). Inhalation of scrap particulate matter are associated with lung cancer, cardiovascular diseases, aggravation of asthma and increased respiratory effects (wheezing and coughing) (Host et al., 2008; Raaschou-Nielsen et al., 2013, WHO, 2019a). Scrap metal recycling has resulted in elevated levels of many other metals, notably lead, including zinc, nickel, and chromium in the surrounding ambient air, soil, and plants (Owoade et al., 2015; Salas-Luevano \& Vega-Carrillo, 2016). To obtain samples of particulate metal concentrations in air necessitates using expensive air equipment to capture samples but, in contrast, snow sampling capture present-day emissions but requires no specialized equipment. The level of heavy metals in the snow in an urban and industrial landscape can effectively measure the atmospheric aerial deposition of air pollutants during the winter season (Sakai, 1988; Elik, 2002; Baltrenaite et al., 2014). Accumulated heavy metals in snow can migrate to the soil and surface water, or air media from wind-blown dust, which may expose humans or animals to these heavy metals (Engelhard et al. 2007; Nakajima \& Aryal, 2018).

\section{Determining Heavy Metals and Pollution Levels}

Numerous studies have analyzed toxic heavy metals in the snow to determine atmospheric pollution levels considering snow to provide a temporary sink for pollutants in the winter season (Sakai et al., 1988; Elik, 2002; Suidek et al., 2015). Melted snow samples are a widely used indicator of air pollution (Brumbaugh \& May, 2008; Carling et al., 2012; Cereceda-Balic et al., 2012). According to Engelhard et al. (2007), adsorption and accumulation of organic and inorganic pollutants to snow in the atmosphere occurs due to the large surface area of snow and the slow pace of snowfall. Small ice crystals and thin liquids in snowflakes act as the medium for adsorption of environmental pollutants (Grannas, 2014; Nazarenko et al., 2016). Hence, this study analyzed snow and as an indicator of heavy metal air pollution (Siudek et al., 2015). Analysis of heavy metals in the snow was undertaken as a cost-effective method to determine concentrations adjacent to the shredder in the MIA and adjacent residen- 
tial, commercial, and roadside levels in SSB. Previous studies assessed the impact of the level of contamination of heavy metals in rain precipitation using pollution indices (Ridgway \& Schimmield, 2002; Yang et al., 2016; Pobi et al., 2019).

\section{Methods and Materials}

\subsection{Sampling Area}

In south-east Winnipeg, the SSB neighborhood borders an industrial area to the north and east, called the MIA and the St. Boniface Industrial Park, as shown in Figure 1. St. Boniface is a low-income community consisting of 58,520 residents (City of Winnipeg, 2019) living in an area of mixed industrial, commercial, and residential land-uses. The MIA includes many diverse industries within a $24.5 \mathrm{~km}^{2}$ area at the junction of the Red and Seine Rivers. At the MIA is a scrap metal recycling plant with an automobile metal shredder and

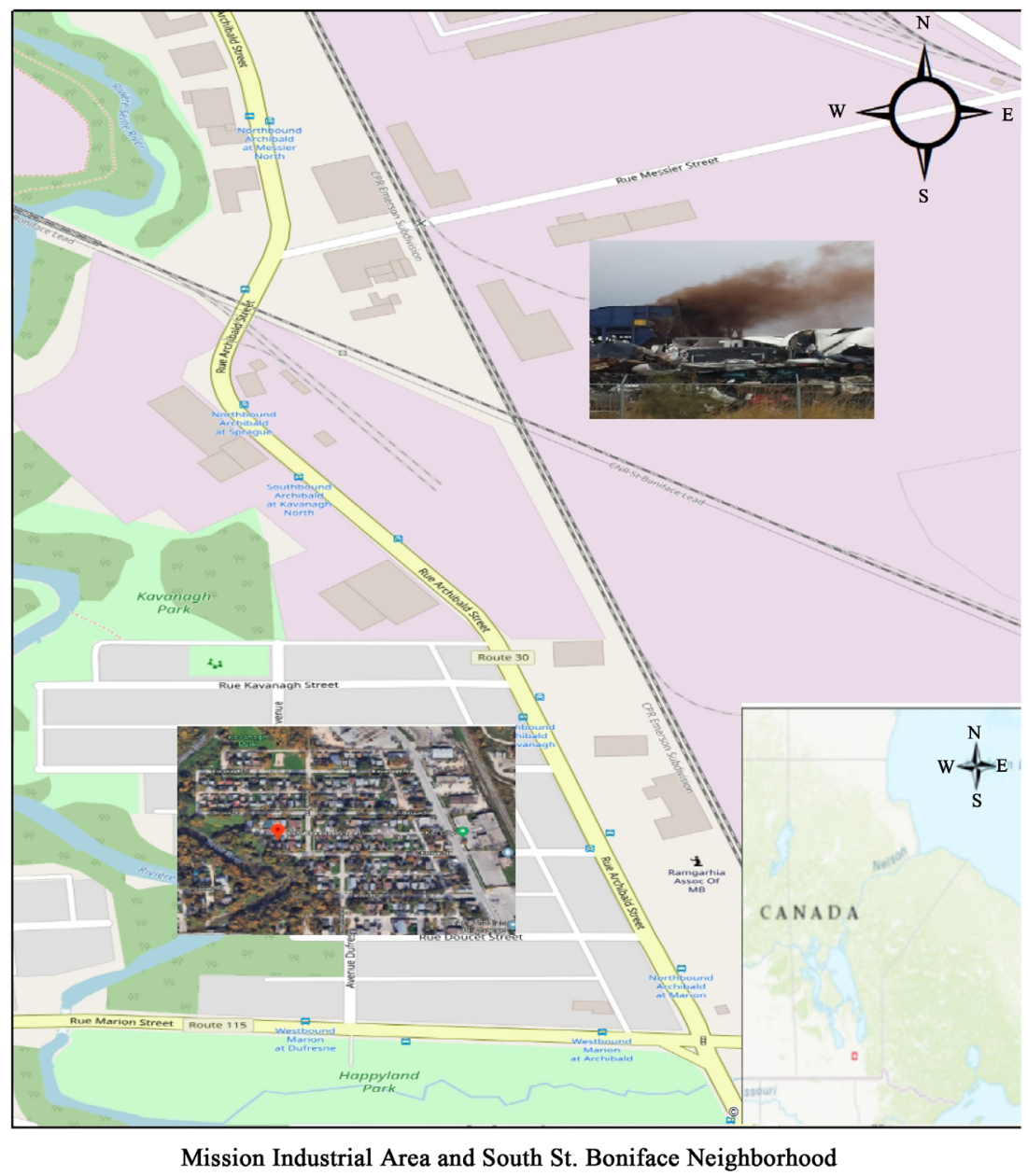

$1 \mathrm{~cm}=0.1 \mathrm{~km}$

Figure 1. Map of the study area showing scrap metal shredder in mission industrial area and South St. Boniface neighborhood, Winnipeg, Canada. 
other metal shredding equipment. In 2017, the scrap metal plant processed and recycled an estimated 178,500 tonnes of scrap metals (Industrial Metals Annual Report, 2017). Downwind of the scrap metal recycling plants to the south are residential streets in the SSB neighborhood with commercial areas that include childcare facility, rental offices, a temple, and an auto repair workshop. The emissions measured in Winnipeg's MIA and at Dufresne neighborhood of South St. Boniface (SSB).

\subsection{Snow Sampling Sites and Procedure}

The GPS coordinates and site characteristics of each sample are listed in Table 1, sample points shown in Figure 2. In total 25 composite samples were collected on 13 March 2019, between 9:30 am and 5:50 pm. These samples included four zones, namely: 1) industrial, 2) dense traffic, 3) commercial, and 4) residential/parkland. In each of these zones, at least four composite snow samples were collected from undisturbed snow, with five samples collected nearby to the property line of the scrap metal recycling plant, to cover all wind directions from

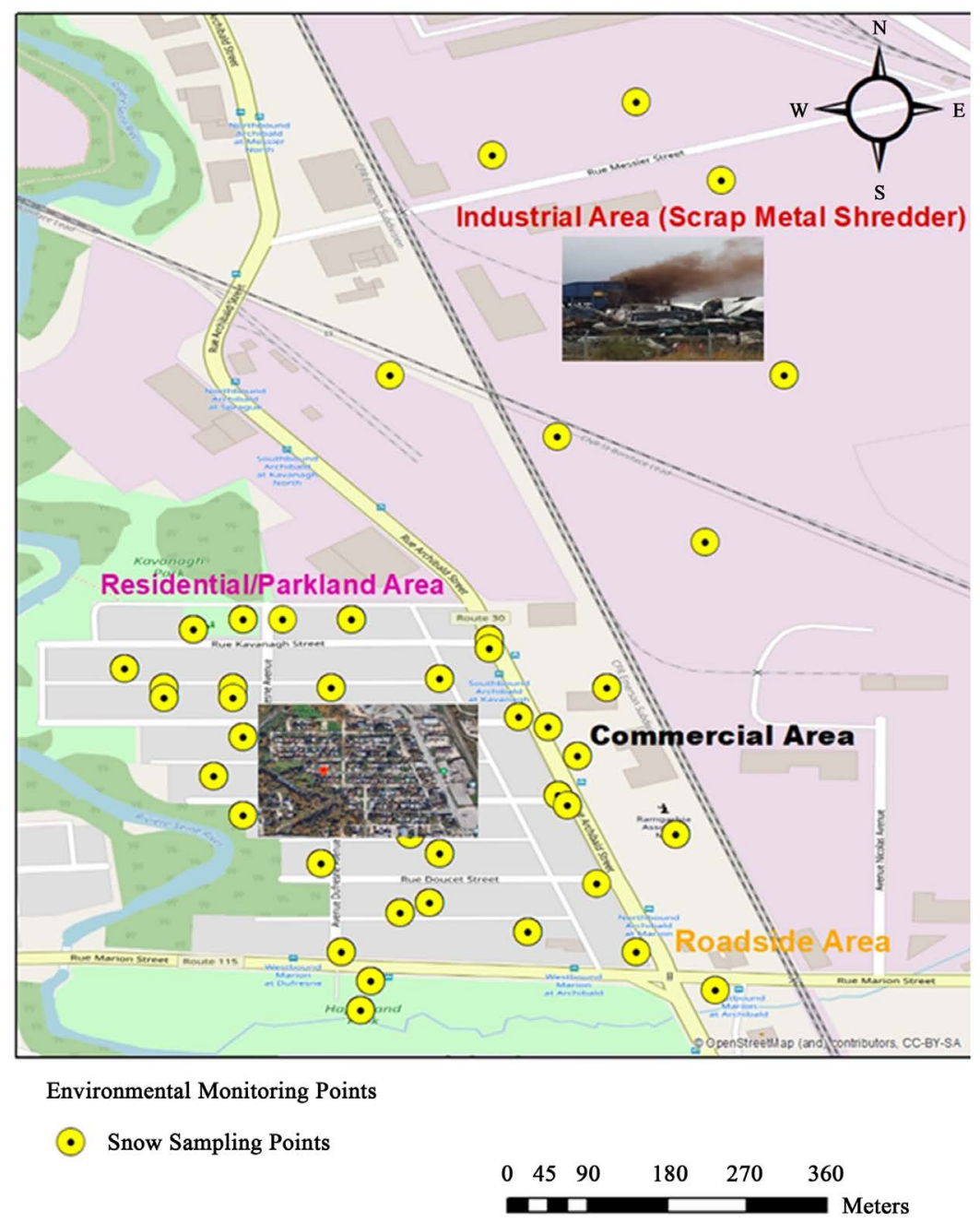

Figure 2. Snow sampling points for heavy metals load in the study area. 
Table 1. GPS coordinates, distance, and characteristics of samples sites.

\begin{tabular}{|c|c|c|c|c|c|}
\hline No. & Zones & $\begin{array}{c}\mathrm{X} \\
\text { Coordinates }\end{array}$ & $\begin{array}{c}\mathrm{Y} \\
\text { Coordinates }\end{array}$ & $\begin{array}{c}\text { Distance } \\
\text { (meters) } \\
\text { from } \\
\text { Shredder } \\
\text { (point 0) }\end{array}$ & Description \\
\hline 0 & Industry & 49.8884 & -97.0988 & 0 & $\begin{array}{l}\text { Auto shredder and scrap } \\
\text { recycling plant }\end{array}$ \\
\hline 1 & Industry & 49.8881 & -97.1016 & 203 & $\begin{array}{c}\text { Downwind of Industry at } \\
\text { Construction storage site } \\
\text { nearby rail track }\end{array}$ \\
\hline 2 & Industry & 49.8884 & -97.0973 & 109 & $\begin{array}{l}30 \text { metres from fence } \\
\text { for auto shredder }\end{array}$ \\
\hline 3 & Industry & 49.8894 & -97.0978 & 133 & $\begin{array}{l}\text { Southwest downwind of } \\
\text { industry } 100 \text { metres from } \\
\text { scrap metal recycling plant }\end{array}$ \\
\hline 4 & Industry & 49.8870 & -97.0992 & 166 & $\begin{array}{l}\text { North downwind of Industry } \\
\text { Nearby rail track opposite } \\
\text { auto shredder }\end{array}$ \\
\hline 5 & Industry & 49.8909 & -97.0991 & 270 & $\begin{array}{l}\text { South Downwind of } \\
\text { Construction storage } \\
\text { site beside Messier road }\end{array}$ \\
\hline 6 & Traffic & 49.8852 & -97.1003 & 375 & $\begin{array}{l}\text { Transit bus stop } 1 \text { at Archibald } \\
\text { Road with moderate traffic }\end{array}$ \\
\hline 7 & Traffic & 49.8845 & -97.1000 & 449 & $\begin{array}{l}\text { Transit bus stop } 2 \text { at Archibald } \\
\text { Road with moderate traffic }\end{array}$ \\
\hline 8 & Traffic & 49.8816 & -97.0969 & 770 & $\begin{array}{l}\text { Heavy traffic area west } \\
\text { bound at Marion Point }\end{array}$ \\
\hline 9 & Traffic & 49.8816 & -97.1035 & 830 & $\begin{array}{l}\text { Heavy traffic area } \\
\text { eastbound at Marion Point }\end{array}$ \\
\hline 10 & Commercial & 49.8876 & -97.1026 & 287 & $\begin{array}{l}\text { Roadside and scrap } \\
\text { metal savage yard }\end{array}$ \\
\hline 11 & Commercial & 49.8849 & -97.0996 & 396 & $\begin{array}{l}\text { Back of auto repair } \\
\text { and nearby rail track }\end{array}$ \\
\hline 12 & Commercial & 49.8845 & -97.0994 & 439 & $\begin{array}{l}\text { Beside kid city and } \\
\text { nearby rail track }\end{array}$ \\
\hline 13 & Commercial & 49.8834 & -97.0986 & 560 & $\begin{array}{l}\text { Sikh temple open field } \\
\text { and nearby rail track }\end{array}$ \\
\hline 14 & Residential/Parkland & 49.8855 & -97.1034 & 463 & $\begin{array}{c}\text { Parkland located on } \\
\text { Kavanagh street NNE from } \\
\text { Scrap metal shredder }\end{array}$ \\
\hline 15 & Residential/Parkland & 49.8816 & -97.1034 & 825 & $\begin{array}{l}\text { Happyland Park beside } \\
\text { busy Marion Road }\end{array}$ \\
\hline 16 & Residential/Parkland & 49.8841 & -97.1033 & 584 & $\begin{array}{l}\text { Cherrier St. 1-NNE } \\
\text { of Industry }\end{array}$ \\
\hline 17 & Residential/Parkland & 49.8840 & -97.1009 & 513 & $\begin{array}{c}\text { Cherrier St. } 2 \\
\text { (Residential/Parkland)-NNE }\end{array}$ \\
\hline
\end{tabular}




\begin{tabular}{|c|c|c|c|c|c|}
\hline \multicolumn{6}{|c|}{ Continued } \\
\hline 18 & Residential/Parkland & 49.8852 & -97.1044 & 537 & Kavanagh St.1-NNE \\
\hline 19 & Residential/Parkland & 49.8856 & -97.1020 & 389 & Kavanagh St. 2-NNE \\
\hline 20 & Residential/Parkland & 49.8843 & -97.1016 & 504 & $\begin{array}{c}\text { Giroux St. 1-downwind } \\
\text { NNE }\end{array}$ \\
\hline 21 & Residential/Parkland & 49.8849 & -97.1032 & 506 & $\begin{array}{c}\text { Giroux St. 2-downwind } \\
\text { NNE }\end{array}$ \\
\hline 22 & Residential/Parkland & 49.8827 & -97.1016 & 671 & $\begin{array}{l}\text { Doucet St. 1-downwind } \\
\text { NNE }\end{array}$ \\
\hline 23 & Residential/Parkland & 49.8831 & -97.1023 & 643 & $\begin{array}{c}\text { Doucet St. } 2 \mathrm{NNE} \\
\text { of Industry }\end{array}$ \\
\hline 24 & Background & 49.7994 & -97.1443 & 10423 & $\begin{array}{c}\text { Sample } 1 \text { Fort Garry } \\
\text { non-industrial } \\
\text { neighbhourhood }\end{array}$ \\
\hline 25 & Background & 49.7989 & -97.1465 & 10532 & $\begin{array}{l}\text { Sample } 2 \text { Fort Garry } \\
\text { non-industrial } \\
\text { neighbhourhood }\end{array}$ \\
\hline
\end{tabular}

the auto shredder. Four samples were collected on the property of nearby businesses, which were downwind to the north of the shredder. We took four undisturbed samples at 12 to 20 meters away from the two main roads of Marion and Archibald streets. Finally, we obtained ten undisturbed snow samples in residents' backyard and parklands in the SSB neighborhood. The background sample (two snow samples) sites were located 15 kilometers away from the MIA and SSB neighborhoods in an area at Silverstone, Fort Richmond, near the University of Manitoba with minimal local/industrial pollution sources (Tchepel et al., 2010).

Accumulated snow cover for each of the sampling points was removed to the depth of $35 \mathrm{~cm}$, which was above ground level to avoid soil contamination. The removed snowpack for each of the sampling points was divided into top, middle and bottom layers at 10 randomly selected points to make up one representative sample for that location (Lancaster \& Keller-Mcnulty, 1998). Each layer filled in a pre-cleaned $500 \mathrm{ml}$ high-density polyethylene (HDPE) bottle, labeled for total metals and total mercury, respectively, and shaken vigorously to have a homogenous mixed composite sample. These sampling procedures were repeated for each sample obtained from the four zones earlier mentioned. Composite snow samples were stored and allowed to melt at room temperature for 8 hours to be able to fill both a $61 \mathrm{ml}$ plastic bottle, adding the preservative of nitric acid $\left(\mathrm{HNO}_{3}\right)$ and a $40 \mathrm{ml}$ mercury-free vials with hydrochloric acid $(\mathrm{HCl})$ preservative on 13 March 2019. Twenty-three composite snow samples from the study site and the two background snow samples were analyzed for heavy metal concentrations by ALS Laboratory on 14 March 2019.

\subsection{Elemental Analysis of Toxic Metals in Snow}

In this study, melted and acidified snow samples were analyzed by the Inductively Coupled Plasma Mass Spectrometry (ICP-MS) at the ALS laboratory in 
Winnipeg using EPA reference EPA 2002.6020B for total metals and EPA 1631E for total mercury in environmental water samples. ALS is an environmental testing laboratory, accredited by the Canadian Association of Laboratory Accreditation (CALA) and Standards Council of Canada (SCC) for International Standards Organization (ISO/IEC) 17,025. This study looked at total Cr analysis, to consider trivalent [Cr (III)] and hexavalent [Cr (VI)]. Hexavalent [Cr (VI)] is a known group 1 carcinogen (Zhitkovich, 2011), while the trivalent $\mathrm{Cr}$ is a vital nutrient but can oxidize and transform into the toxic hexavalent $\mathrm{Cr}$ which necessitated the need to measure total Cr (Government of Canada, 2015).

\subsection{Method of Statistical and Spatial Analysis}

The distribution of data in all the sampling points was determined by the normality test. Statistical analysis with SPSS version 24 was performed to analyze metal levels in snow and non-parametric tests using Spearman rank correlation coefficient and Kruskal-Wallis Test across the sampling sites. Also, the nonlinear regression model was used to predict the relationship between the concentration of heavy metals in snow samples across distances to the metal shredder.

Kriging interpolation technique was applied with geographic information system (GIS) methods to map out air pollution in environmental samples, as point data by Akintuyi et al. (2014) and Oyedepo et al., (2019). In our study, kriging interpolation, a geostatistical analysis tool on ArcMap 10.6, was primarily used to indicate the hotspot areas for the heavy metals concentrations measured in snow. The kriging interpolation analytical tool uses a semivariogram to describe the relationship that exists between the concentration of heavy metals in the samples and their respective distances (McGrath et al., 2004; Ha et al., 2014). The concentration of each heavy metal and the coordinates (latitude and longitude) for each sample point were stored in an excel spreadsheet to create a shapefile on ArcMap 10.6 to support the kriging interpolation analysis.

\section{Evaluation of Heavy Metals Load in Snow by Pollution Indices}

Three different pollution indices were calculated for each heavy metal analyzed in each snow sample calculating the contamination factor (CF), degree of contamination (DOC), and pollution load index (PLI) of heavy metals concentration in snow samples at different sampling sites. Pollution indices have been applied to assess the level of contamination of heavy metals in wet precipitate/watersediment to describe the potential adverse effect (Sakai et al., 1988; Ridgway \& Schimmield, 2002; Yang et al., 2016; Pobi et al., 2019). The pollution indices indicate the degree of contamination from industrial activities compared to background levels (Ogundele et al., 2017; Olawoyin et al., 2018).

\section{Contamination Factor, Degree of Contamination and Pollution Load Indices}

$\mathrm{CF}$ was determined from the ratio determined by the concentration of each heavy 
metal in the snow sample divided by the concentration of heavy metals in the background snow sample (Hakanson, 1980; Shen et al., 2019).

$$
\mathrm{CF}=\frac{\text { mean conc. of each heavy metals from each sample area }}{\text { mean conc. of heavy metals in background samples }}
$$

$\mathrm{CF} \leq 1=$ low; $\mathrm{CF} \leq 3=$ moderate; $\mathrm{CF} \leq 6=$ high; and $\mathrm{CF}>6=$ very high.

Degree of contamination (DOC) was computed as the sum of CF for each heavy metal above the mean concentration of background sample (Backman et al., 1998) according to the following formula:

$$
\mathrm{DOC}=\sum_{i=1}^{n} \mathrm{CF}_{i}
$$

$\mathrm{DOC} \leq 1=$ low; $1 \leq \mathrm{DOC} \leq 3=$ medium; and DOC $>3=$ high.

Pollution Load Index (PLI) provided a simple and comparative means of assessing soil, sediment or water quality (Tomlinson et al., 1980; Pobi et al., 2019). PLI calculated the geometric mean of CF value of a number of heavy metals estimated at the contaminated site by using the following equation (Pobi et al., 2019):

$$
\mathrm{PLI}=\left(\mathrm{CF}_{1} \times \mathrm{CF}_{2} \times \mathrm{CF}_{3} \times \cdots \times \mathrm{CF}_{n}\right)^{1 / n} \text { or } \mathrm{PLI}=\sqrt[n]{\mathrm{CF}_{1} \times \mathrm{CF}_{2} \times \mathrm{CF}_{3} \times \cdots \times \mathrm{CF}_{n}}
$$

where: $n$ is the number of different heavy metals ( $n=8$ in this study): and, CF is the contamination factor of individual heavy metals present in the snow samples.

With PLI $<1$ = background, PLI $>1$ = contamination.

\section{Result and Discussion}

\subsection{Heavy Metals Load in Snow Samples}

Table 2 provides the summary statistics of the heavy metals in the snow samples. The observed mean concentrations for all heavy metals tested were higher than their background concentration values, except for some metals namely As, $\mathrm{Ni}$ and $\mathrm{Hg}$ that were below the detection limits in some of the samples sites as well as in some residential/parkland sample points. $\mathrm{Pb}$ and $\mathrm{Zn}$ had the highest concentrations of heavy metals in snow samples collected for the different five sample points in this study, as shown in Table 2.

The mean concentration of $\mathrm{Zn}(545.5 \mu \mathrm{g} / \mathrm{l})$ near the fenceline of scrap metal recycling showed higher pollution levels than other elements analyzed in this study. The mean concentration of $\mathrm{Zn}$ in this study agreed with the $\mathrm{Zn}$ measurements in snow as the highest heavy metals reported by Phillips et al. (1986) snow analysis near smelters in Flin Flon, Manitoba. Also, the $\mathrm{Zn}$ level in our study was 10 times higher than the $53 \mu \mathrm{g} / \mathrm{l}$ reported by Sakai et al. (1988). This higher concentration in our study suggests scrap metal shredding emissions and other industrial air pollution sources. Emissions, like zinc dust and fumes, could be attributed to the processing and shredding of non-ferrous metals that contain zinc pipes and radiators, zinc in the die-cast alloy in cars, and tire shredding. Similarly, the mean concentration of Zn (78.85 and $53.35 \mu \mathrm{g} / \mathrm{l})$ in 
Table 2. Summary descriptive statistics of toxic heavy metals in snowpack samples.

\begin{tabular}{|c|c|c|c|c|c|c|c|c|c|}
\hline $\begin{array}{l}\text { Zone (Com } \\
\text { Snow Sample L }\end{array}$ & $\begin{array}{l}\text { posite } \\
\text { ocations) }\end{array}$ & $\begin{array}{c}\mathrm{Pb} \\
(\mu \mathrm{g} / \mathrm{l})\end{array}$ & $\begin{array}{c}\text { As } \\
(\mu \mathrm{g} / \mathrm{l})\end{array}$ & $\begin{array}{c}\mathrm{Cr} \\
(\mu \mathrm{g} / \mathrm{l})\end{array}$ & $\begin{array}{c}\mathrm{Cd} \\
(\mu \mathrm{g} / \mathrm{l})\end{array}$ & $\begin{array}{c}\mathrm{Ni} \\
(\mu \mathrm{g} / \mathrm{l})\end{array}$ & $\begin{array}{c}\mathrm{Zn} \\
(\mu \mathrm{g} / \mathrm{l})\end{array}$ & $\begin{array}{c}\mathrm{Mn} \\
(\mu \mathrm{g} / \mathrm{l})\end{array}$ & $\underset{(\mu \mathrm{g} / \mathrm{l})}{\mathrm{Hg}}$ \\
\hline \multirow{6}{*}{ Industrial } & Mean & 30.1 & 0.33 & 4.29 & 0.62 & 3.71 & 545.4 & 30.0 & 0.062 \\
\hline & $\mathrm{N}$ & 5 & 5 & 5 & 5 & 5 & 5 & 5 & 5 \\
\hline & Std. Deviation & 31.4 & 0.22 & 4.00 & 0.53 & 3.73 & 651 & 24.7 & 0.08 \\
\hline & Median & 18.5 & 0.27 & 3.09 & 0.40 & 2.52 & 410 & 25.4 & 0.03 \\
\hline & Minimum & 10.2 & 0.15 & 1.13 & 0.21 & 0.99 & 39.9 & 11.7 & ND \\
\hline & Maximum & 85.8 & 0.72 & 10.8 & 1.53 & 10.2 & 1660 & 72.2 & 0.20 \\
\hline \multirow{6}{*}{ Roadside } & Mean & 5.55 & 0.47 & 2.20 & 0.09 & 1.82 & 78.5 & 30.9 & ND \\
\hline & $\mathrm{N}$ & 4 & 4 & 4 & 4 & 4 & 4 & 4 & 4 \\
\hline & Std. Deviation & 5.37 & 0.40 & 2.15 & 0.07 & 1.87 & 63.1 & 25.8 & ND \\
\hline & Median & 4.15 & 0.36 & 1.57 & 0.08 & 1.45 & 64.7 & 23.1 & ND \\
\hline & Minimum & 0.69 & 0.14 & 0.43 & 0.01 & ND & 18.6 & 9.52 & ND \\
\hline & Maximum & 13.2 & 1.02 & 5.21 & 0.18 & 4.37 & 166 & 67.8 & ND \\
\hline \multirow{6}{*}{ Commercial } & Mean & 4.77 & 0.30 & 0.98 & 0.06 & 0.86 & 53.4 & 11.2 & ND \\
\hline & $\mathrm{N}$ & 4 & 4 & 4 & 4 & 4 & 4 & 4 & 4 \\
\hline & Std. Deviation & 2.37 & 0.09 & 0.26 & 0.02 & 0.18 & 21.2 & 1.24 & ND \\
\hline & Median & 4.05 & 0.28 & 0.93 & 0.06 & 0.85 & 52.4 & 11.1 & ND \\
\hline & Minimum & 2.89 & 0.22 & 0.74 & 0.04 & 0.65 & 28.5 & 9.94 & ND \\
\hline & Maximum & 8.07 & 0.41 & 1.31 & 0.08 & 1.08 & 80.2 & 12.8 & ND \\
\hline \multirow{6}{*}{ Residential/Parkland } & Mean & 1.54 & 0.08 & 0.32 & 0.03 & 0.57 & 19.8 & 6.56 & ND \\
\hline & $\mathrm{N}$ & 10 & 10 & 10 & 10 & 10 & 10 & 10 & 10 \\
\hline & Std. Deviation & 1.56 & 0.08 & 0.18 & 0.02 & 1.52 & 10.8 & 1.78 & ND \\
\hline & Median & 0.99 & 0.05 & 0.26 & 0.02 & 0.00 & 16.2 & 6.70 &. $\mathrm{ND}$ \\
\hline & Minimum & 0.51 & ND & 0.14 & 0.01 & ND & 9.30 & 4.33 & ND \\
\hline & Maximum & 5.04 & 0.21 & 0.74 & 0.06 & 4.82 & 43.3 & 10.2 & ND \\
\hline \multirow{6}{*}{ Background } & Mean & 0.20 & ND & 0.01 & 0.21 & 0.37 & 8.25 & 3.63 & ND \\
\hline & $\mathrm{N}$ & 2 & 2 & 2 & 2 & 2 & 2 & 2 & 2 \\
\hline & Std. Deviation & 0.01 & 0.00 & 0.003 & 0.06 & 0.52 & 1.06 & 1.03 & ND \\
\hline & Median & 0.20 & ND & 0.01 & 0.22 & 0.37 & 8.25 & 3.63 & ND \\
\hline & Minimum & 0.19 & ND & 0.01 & 0.17 & ND & 7.50 & 2.90 & ND \\
\hline & Maximum & 0.20 & ND & 0.01 & 0.26 & 0.74 & 9.00 & 4.36 & ND \\
\hline
\end{tabular}

roadside and nearby commercial areas in this study was within the range (29.0 $143.0 \mu \mathrm{g} / \mathrm{l}$ ) detected by Loranger et al. (1996) in the snow cover of an urban expressway in Montreal, Canada. Elevated zinc concentration in roadside snow suggests deposition of $\mathrm{Zn}$ caused by road deposition of dust from tire wear and road abrasion (Adamiec et al., 2016). 
The mean concentration of $\mathrm{Pb}(30 \mu \mathrm{g} / \mathrm{l})$ measured in scrap metal recycling snow cover of Winnipeg was approximately seven times lower than the mean value of $205.5 \mu \mathrm{g} / \mathrm{l}$ observed by Engelhard et al. (2007) in Innsbruck, Austria. Both mean $\mathrm{Pb}$ concentrations from scrap metal recycling in Winnipeg and the mean concentration of $\mathrm{Pb}(1.4 \mu \mathrm{g} / \mathrm{l})$ in the residential/parkland snow samples in Winnipeg were significantly higher than the concentration $(0.01 \mu \mathrm{g} / \mathrm{l})$ reported by Barbante et al. (2003) in snow deposits in Central Greenland. The concentration of $\mathrm{Pb}$ detected in the industrial snow cover sample in this study ranged between 10 and $85.8 \mu \mathrm{g} / \mathrm{l}$, which is less than the $\mathrm{Pb}$ concentration reported in the melted snow-cap heavy metals (Kristynte et al., 2013). This is likely attributed to the wide use of lead in industrial applications and the presence of lead in most recycled non-ferrous scrap metals (OSHA, 2008; USEPA, 2009; WHO, 2019a).

Regulations and operating licenses of auto dismantlers and automobile shredders prohibit recycling lead-acid batteries and subsequent sorting and removal of battery terminals before shredding. However, other pathways of lead particle emission from scrap metals, such as lead pipes, leaded-steel components, castmetal parts or lead-based coating, cannot be easily removed through magnetic sorting or visual examination (OSHA, 2008; USEPA, 2009). Thus, these lead components can result in the emissions of significant concentrations of lead particles during scrap metal shredding.

The mean concentrations of As in melted snow cover in the sample sites ranged between 0.08 and $0.47 \mu \mathrm{g} / \mathrm{l}$, respectively. This concentration is 1.5 to 9 times lower than the $0.7 \mu \mathrm{g} / \mathrm{l}$ mean value observed by Siudek et al. (2015) in Poznan, central Poland, for an industrial snow sample area linked to polluted air masses from urban/industrial air emissions. Mean values of As in Winnipeg exceeded Douglas \& Stum's (2004) mean value of $0.09 \mu \mathrm{g} / \mathrm{l}$ in snow cover across Northwestern Alaska, USA. The lower value reported by Douglas \& Stum (2004) is the lowest mean value reported for arsenic in the study's residential/parkland snow sampling site of Winnipeg. The variations between the As concentrations reported in the identified studies linked to different anthropogenic operations peculiar to each study area and other site characteristics, such as meteorology and the sampling period (Siudek et al., 2015). According to Sanchez-Rodas et al. (2007), non-ferrous metal production is the most significant human-made source of arsenic emissions in an urban/industrial area atmosphere. For example, the higher mean concentration of arsenic in $\mathrm{PM}_{2.5}$ air samples was found to be over 300 times $\left(0.20-0.47 \mu \mathrm{g} / \mathrm{m}^{3}\right)$ above the WHO guidelines of $0.00066 \mu \mathrm{g} / \mathrm{m}^{3}$ in scrap metal smelting electric arc furnace emissions by Owoade et al. (2015).

In our study, mean concentrations of $\mathrm{Ni}(0.860-3.712 \mu \mathrm{g} / \mathrm{l})$ were significantly higher than the average Ni concentration $(0.72 \mu \mathrm{g} / \mathrm{l})$ reported by Cereceda-Balic et al. (2012) in the snow of Cerro Colorado, Chile. Also, the Ni value in this study is higher than the value $(0.68 \mu \mathrm{g} / \mathrm{l})$ reported by Carling et al. (2012) in the snowpack of Utah, USA. However, in an industrial area in Poznan, Central Poland, Siudek et al. (2015) measured average Ni $(3.77 \mu \mathrm{g} / \mathrm{l})$, was similar to the 
highest mean value reported for our study in Winnipeg. The highest concentration of Ni observed in this study can be attributed to the possible wet and dry deposition of $\mathrm{Ni}$ dust/fumes generated during scrap metal handling and shredding operation and high recyclable nature of nickel.

Also, Cd concentrations ( $0.03-0.62 \mu \mathrm{g} / \mathrm{l})$ detected in this study's snow sample is significantly lower than the mean value of $3.87 \mu \mathrm{g} / \mathrm{l}$ reported by Engelhard et al. (2007) in the urban snow sample of Innsbruck, Austria. The higher concentration of Cd reported by Engelhard et al. (2007) was linked to highway traffic and unidentified anthropogenic source in an urban environment. The current study's highest mean $\mathrm{Cd}$ value of $0.62 \mu \mathrm{g} / \mathrm{l}$ nearby the fenceline of scrap metal recycling operations was over seven times higher than that reported by Siudek et al. (2015). Cd is an example of a rare element of non-ferrous metals. Cadmium's high concentration in our study suggests a possible deposition from handling and processing of non-ferrous scrap metals and shredding of scrap metals coated with cadmium paint (OSHA, 2008). Mean values of Cd in other sampled sites in Winnipeg $0.03,0.06,0.09$, and $0.21 \mu \mathrm{g} / \mathrm{l}$, respectively, ranged within the values detected by Douglas \& Stum (2004), Gabrielli et al. (2006) and Siudek et al. (2015).

The mean concentration of total $\mathrm{Cr}(0.300-4.29 \mu \mathrm{g} / \mathrm{l})$ reported in our study showed higher variations than $\mathrm{Cr}$ values observed in other snow pollution studies. Specifically, the amount of $\mathrm{Cr}$ at $4.29 \mu \mathrm{g} / \mathrm{l}$ in snow samples near recycling operations was significantly higher than the values of $0.01,0.40$, and $0.77 \mu \mathrm{g} / \mathrm{l}$, reported by Carling et al. (2012), Cereceda-Balic et al. (2012) and Suidek et al. (2015). In contrast, the study of heavy metals in inner urban snow in Japan (Sakai, 1988) detected the mean value of $\mathrm{Cr}$ at $9.30 \mu \mathrm{g} / \mathrm{l}$; over two times the maximum mean value of $4.29 \mu \mathrm{g} / \mathrm{l}$ observed in Winnipeg.

The group 1 carcinogen levels, namely $\mathrm{As}, \mathrm{Cd}, \mathrm{Cr}$, and $\mathrm{Ni}$, were all found to be significantly higher in accumulated snow near the scrap metal shredder than levels observed in the background snow samples. These carcinogenic heavy metals alongside high concentrations of $\mathrm{Zn}$ and $\mathrm{Pb}$ fit the footprint of contamination and hazardous emissions. Other possible sources of heavy metals include vehicular and industrial smoke/dust particles emission as well as tire rub-off on the road (Vasić et al., 2012; Krastinyte et al., 2013). However, the heavy metals deposition and accumulation in snow samples were significantly higher in the industrial area along the fenceline of the scrap metal shredder than every other sample areas.

\subsection{Result of Non-Parametric Tests Using Spearman Rank Correlation and Kruskal-Wallis Test}

All the p-values were $<0.05$, according to the Kolmogorov-Smirnov Test and Shapiro-Wilk test, indicating non-normally distributed data for heavy metals concentrations in snow samples in Table 3. As a result, we applied Spearman rank correlation and Kruskal-Wallis as non-parametric tests for the co-occurrence and statistical significant levels of heavy metals in snow across the sample sites. 
Table 3. Tests of normality.

\begin{tabular}{ccccccc}
\hline & \multicolumn{3}{c}{ Kolmogorov-Smirnov $^{\mathrm{a}}$} & \multicolumn{3}{c}{ Shapiro-Wilk } \\
\cline { 2 - 7 } & Statistic & $\mathrm{Df}$ & Sig. & Statistic & $\mathrm{df}$ & Sig. \\
\hline $\mathrm{Pb}$ & 0.319 & 25 & $0.000^{*}$ & 0.469 & 25 & $0.000^{*}$ \\
$\mathrm{As}$ & 0.202 & 25 & 0.010 & 0.801 & 25 & $0.000^{*}$ \\
$\mathrm{Cr}$ & 0.330 & 25 & $0.000^{*}$ & 0.605 & 25 & $0.000^{*}$ \\
$\mathrm{Cd}$ & 0.301 & 25 & $0.000^{*}$ & 0.540 & 25 & $0.000^{*}$ \\
$\mathrm{Ni}$ & 0.280 & 25 & $0.000^{*}$ & 0.655 & 25 & $0.000^{*}$ \\
$\mathrm{Zn}$ & 0.369 & 25 & $0.000^{*}$ & 0.410 & 25 & $0.000^{*}$ \\
$\mathrm{Mn}$ & 0.323 & 25 & $0.000^{*}$ & 0.629 & 25 & $0.000^{*}$ \\
$\mathrm{Hg}$ & 0.495 & 25 & $0.000^{*}$ & 0.337 & 25 & $0.000^{*}$ \\
\hline
\end{tabular}

Lilliefors Significance Correction; ${ }^{*}=$ statistical significance at $p<0.01$.

The rank coefficient showed strong positive correlation coefficients $r_{s}=0.744$ - 0.949 and statistically significant $p=0.01$, for $\mathrm{Pb}, \mathrm{As}, \mathrm{Cr}, \mathrm{Cd}, \mathrm{Ni}$, and $\mathrm{Zn}$. Also, moderate correlation coefficient $r_{s}=0.527-0.586$ and statistically significant $p=$ 0.01, between $\mathrm{Hg}-\mathrm{Pb}, \mathrm{Hg}-\mathrm{Zn}, \mathrm{Hg}-\mathrm{Ni}, \mathrm{Hg}-\mathrm{Cr}$, and $\mathrm{Hg}$-Cd were observed. The moderate correlation coefficient for mercury with other heavy metals can be attributed to the low detectable levels of mercury, which was detected in three out of the five industrial samples.

Furthermore, the non-parametric Kruskal-Wallis $\mathrm{H}$ test showed a statistically significant difference between heavy metals in groups of composite snow sample sites, $\mathrm{N}=23$; $\mathrm{X}^{2}(2)=14.23, p=0.003$, with a mean rank $\mathrm{Pb}$ value 20.80 for Industrial, 12.50 for roadside, 13.25 for commercial, and 6.90 for residential/parkland. The Kruskal-Wallis $\mathrm{H}$ test for other trace elements statistical significant for different snow sample sites are presented in Table 4.

\subsection{Discussion of Pollution Indices in Snow Samples}

Table 5 presents the results for the contamination factors (CF), degree of contamination (DOC) and pollution load index (PLI). The DOC values were 249, 50,48 , and 13 for the industrial, roadside, commercial, and residential/parkland snow sites, respectively. These four areas were all considered by this DOC measure to be highly contaminated. These DOC values showed that the industrial contamination is roughly five times more contaminated than that for the road or commercial areas and almost 20 times more contaminated compared to the residential/parkland. The road and commercial sites are roughly four times more contaminated than the residential/parkland. However, the lowest PLI value (0.6) in the residential/parkland area did not consider this area contaminated, but that the others were at 4.1 for shredder, 2.2 for roadside and 1.9 for commercial areas.

The CF of each toxic heavy metal in snow was calculated for four land use categories (industrial, commercial, roadside, and residential/parkland). The CF 
Table 4. Kruskal-Wallis test for heavy metals distribution in snow.

\begin{tabular}{ccccccc}
\hline Heavy Metals & $\mathrm{X}^{2}(2)$ & $p$-value & $\begin{array}{c}\text { Mean Rank } \\
\text { (Industrial) }\end{array}$ & $\begin{array}{c}\text { Mean Rank } \\
\text { (Roadside) }\end{array}$ & $\begin{array}{c}\text { Mean Rank } \\
\text { (Commercial) }\end{array}$ & $\begin{array}{c}\text { Mean Rank } \\
\text { (Residential/Parkland) }\end{array}$ \\
\hline Lead (Pb) & 14.229 & $0.003^{*}$ & 20.80 & 12.50 & 13.25 & 6.90 \\
Arsenic (As) & 13.365 & $0.004^{*}$ & 16.40 & 16.00 & 17.13 & 6.15 \\
Chromium (Cr) & 16.342 & $0.001^{*}$ & 19.40 & 16.00 & 14.38 & 5.75 \\
Cadmium (Cd) & 14.951 & $0.002^{*}$ & 21.00 & 12.75 & 13.00 & 6.80 \\
Nickel (Ni) & 10.645 & $0.014^{*}$ & 18.60 & 14.75 & 12.50 & 7.40 \\
Zinc (Zn) & 15.24 & $0.002^{*}$ & 19.40 & 15.25 & 14.50 & 6.00 \\
Manganese (Mn) & 16.567 & $0.001^{*}$ & 18.80 & 17.50 & 13.750 & 10.50 \\
Mercury (Hg) & 11.812 & $0.008^{*}$ & 17.40 & 10.50 & 5.70 \\
\hline
\end{tabular}

* $=$ statistical significance at $p<0.05$.

Table 5. Three different pollution indices applied to the four different land uses for six heavy metals.

\begin{tabular}{ccccc}
\hline Pollution Indices & Industrial & Roadside & Commercial & Residential/Parkland \\
\hline $\begin{array}{c}\text { Degree of Contamination } \\
\text { (DOC) }\end{array}$ & 249 & 50 & 48 & 13 \\
Pollution Load Index (PLI) & 4.1 & 2.2 & 1.9 & 0.6 \\
CF for Pb & 151 & 28 & 24 & 7 \\
CF for Zn & 66 & 6 & 9 & 2 \\
CF for Ni & 20 & 10 & 5 & 1.4 \\
CF for $\mathrm{Mn}$ & 8 & 3 & 9 & 2 \\
CF for Cr & 4 & 2 & 1 & 0.3 \\
CF for $\mathrm{Hg}$ & $0.03-0.2(\mu \mathrm{g} / \mathrm{l})$ & Not Detected & Not Detected & Not Detected \\
\hline
\end{tabular}

With: $\mathrm{CF} \leq 1=$ low; $\mathrm{CF} \leq 3=$ moderate; $\mathrm{CF} \leq 6=$ high, and $\mathrm{CF}>6=$ very high. With: $\mathrm{DOC} \leq 1=$ low; $\leq 1$ $\mathrm{DOC} \leq 3=$ medium; and $\mathrm{DOC}>3=$ high. With: $\mathrm{PLI}<1=$ background, $\mathrm{PLI}>1=$ contamination.

values for $\mathrm{Mn}, \mathrm{Pb}, \mathrm{Zn}$, and $\mathrm{Ni}$ indicated moderate to very high levels of contamination in the industrial, roadside, and commercial areas. The largest $\mathrm{CF}$ values for $\mathrm{Pb}$ (151), $\mathrm{Zn}$ (66), and $\mathrm{Ni}$ (20) for industrial snow samples suggests predominant deposition came from the scrap metal recycling operations. Chromium also showed moderate contamination levels in the industrial $(\mathrm{CF}=4.3)$ and roadside $(\mathrm{CF}=2.2)$ areas, respectively. $\mathrm{CF}$ values for $\mathrm{As}$ and $\mathrm{Cd}$ in all the sample sites was less than $\mathrm{CF}>1$, which suggests low contamination levels for these two metals. However, some CF values were low in the residential/parkland sample site with the exception of $\mathrm{Mn}$ (2), $\mathrm{Ni}$ (1.4) and $\mathrm{Zn}$ (2), respectively, which showed moderately contaminated levels at $\mathrm{CF} \leq 3$. Also, the residential/parkland zone snow samples showed highly contaminated levels for $\mathrm{Pb}$ (7), at $\mathrm{CF}>6$ indicates very high contamination.

Wind dispersion, subsequent wet (rain and snow precipitates), and dry deposition of particulate matter on trees, plants, soil, and snow are crucial to the nat- 
ural cleansing of the polluted atmosphere (Soriano et al., 2012; Nazarenko et al., 2016). These deposits serve as a temporary and permanent sink of hazardous air pollutants. In this case, particulate heavy metals settle on surfaces such as plants, soil, and snow. In our study, neurotoxic and carcinogenic heavy metals ( $\mathrm{Pb}, \mathrm{Mn}$, and $\mathrm{Ni}$ ), as well as essential trace elements $(\mathrm{Zn}$ and $\mathrm{Mn})$ at very high concentrations, pose a toxic health risk (Sanders et al., 2009; Claus Henn et al., 2010; IARC, 2020).

Previous measurements of heavy metals in particulate matter emission during scrap metal processing found average levels of $\mathrm{Pb}, \mathrm{Mn}, \mathrm{Ni}, \mathrm{Cr}$, and $\mathrm{Cd}$ exceeded the safe limit levels in airborne particles recommended by WHO and USEPA (Ogundele et al. 2017). In the context of this study design and study area, heavy metals measured in snow as a low-cost indicator of air pollution in the scrap metal recycling area and other neighboring areas adopted as the sample sites. Although no provincial or existing guidelines or limits for heavy metals load in snow cover, but pollution indices model estimated high contamination levels and pollution load for $\mathrm{Pb}, \mathrm{Zn}, \mathrm{Ni}$, and $\mathrm{Mn}$ in the order of industrial $>$ roadside > commercial > residential/parkland.

The highest $\mathrm{CF}$ for $\mathrm{Pb}$ under all land uses is explained by $\mathrm{Pb}$ being ubiquitous in metal products, and most recycled metal after iron (ILO, 2004; OSHA, 2008), as well as previously being used in leaded gasoline and paint. Health risks from exposure to $\mathrm{Pb}$ include anemia, weakness, brain, and kidney damage (CDC, 2018) and are more pronounced in children than adults impacting their brain and nervous system development (WHO, 2019b). Consequently, lead is a global public health concern. According to the Centre for Disease Control (2018), inhalation of $\mathrm{Pb}$ is the primary source of absorption of higher levels of $\mathrm{Pb}$ in the human body than any other route of exposure. Children are also at the risk of 4 5 times ingestion of $\mathrm{Pb}$ than adults because of their hand to mouth behavior, and long term exposure in the adult can result in profound health impacts like high blood pressure and kidney damage (WHO, 2019b).

$\mathrm{Ni}$ is a toxic and carcinogenic heavy metal that had a very high $\mathrm{CF}$ in the industrial and roadside samples. Naturally, Ni occurs at low levels; however, the extensive industrial use of $\mathrm{Ni}$ has increased its occurrence level in the environment. For example, nickel is a non-ferrous metal like lead, used for stainless steel, aluminum alloys, and electroplating when processed and shred as scrap may be present as fume or dust. The deposition of Ni scrap dust and fumes may be attributed to the high contamination factor reported for $\mathrm{Ni}$ in snow and inhalation. Ni dust poses numerous public health risks when inhaled at high concentrations, causing pneumonitis and the development of nose, lung, larynx, and prostate cancer (Lenntech, 2020). CF values for $\mathrm{Zn}$ and $\mathrm{Mn}$ range between very high to moderate levels of contamination, respectively. $\mathrm{Zn}$ has the second-highest level of CF in the industrial snow samples and other sample sites, which can be linked to the fact that Zinc is the fourth most widely used metals in the world (Tolcin, 2015). Zinc emissions poses a high hazard level from scrap metal processing (Ogundele et al., 2017). Consequently, in this study, the high con- 
centration of $\mathrm{Zn}$ in snow sampled at the property line of the scrap metal recycler suggests a recent deposition of zinc dust and fumes on snow cover emanating from the scrap metal recycler.

Unlike $\mathrm{Pb}$ and $\mathrm{Ni}$, which are neurotoxins and carcinogens in humans, $\mathrm{Zn}$ is an essential nutrient needed for numerous bodily functions. $\mathrm{Zn}$ is needed in small amounts for cellular metabolism of nutrients and a healthy immune system through dietary intake (Darnton-Hill, 2013; Nordqvist, 2017). However, overexposure to $\mathrm{Zn}$ as an environmental pollutant can be detrimental to human health from inhalation of contaminated air linked to Zinc dust and fumes from metal processing and recycling industries (ATSDR, 2005; OSHA, 2008). Development of short-term disease known as metal fume fever caused by the inhalation of zinc dust and fumes but is reversible when exposure stops (ATSDR, 2005).

\subsection{Nonlinear Regression Analysis of Heavy Metals Concentration}

In this study, we applied the nonlinear regression to statistically estimate the relationship between heavy metals concentrations in snow and the distance of scrap metal shredder to the sample sites. The Polynomial Regression was applied to determine the variation trend of each heavy metal concentration, with the formula shown in Equation (4) below:

$$
Y=B_{0}+B_{1} X+B_{2} X^{2}
$$

where $Y$ is the heavy metal concentration, $X$ is the distance of the snow sample point to the scrap metal shredder, $B_{0}, B_{1}$, and $B_{2}$ are the model's coefficients.

The regression curve of each heavy metals' concentration to the sample site distance from the scrap metal shredder are shown in Figures 3-9. Distance of the sample sites to shredder is 100 to 270 meters in the industrial area, 287 to 560 in the commercial area, 370 to 830 meters in the roadside area, 463 to 671 meters in the residential/parkland area. All heavy metals concentrations significantly decreased as the distance of the sample locations increased from the scrap metal shredder. The $\mathrm{R}$ square values of the regression models for the heavy metals are $0.585(\mathrm{Cd}), 0.462(\mathrm{~Pb}), 0.423(\mathrm{Zn}), 0.343(\mathrm{Cr}), 0.343(\mathrm{Ni}), 0.244(\mathrm{Mn})$, and 0.069 (As), respectively.

The highest concentration of $\mathrm{Cd}(1.53 \mu \mathrm{g} / \mathrm{l})$, shown in Figure 3, at 133 meters from the scrap metal shredder decreased exponentially to $0.01 \mu \mathrm{g} / \mathrm{l}$ at 400 to 500 meters in the residential/parkland area. Peak concentrations of $\mathrm{Cd}$ in high proximity with the shredder may be the result of cadmium in paints, alloys, pigments, and batteries (Apanpa-Qasim et al., 2016). Pb concentration also decreased from $85.8 \mu \mathrm{g} / \mathrm{l}$ at 133 meters from the scrap metal shredder to 13.2, 8.07, and $5.04 \mu \mathrm{g} / \mathrm{l}$, respectively, for roadside, commercial and residential/parkland areas. Also, as shown by the scatter plots and regression curves, high metals load in roadside area at 450 meters from the shredder suggests deposition from traffic-related emissions (Khalid et al., 2018). With the exception of arsenic (As), all 


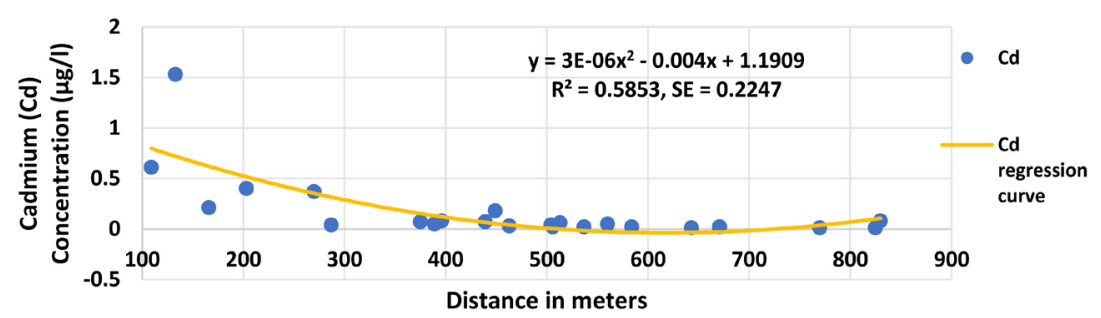

Figure 3. Relationship between Cadmium (Cd) concentration in snow versus distance of the sample points to the scrap metal shredder.

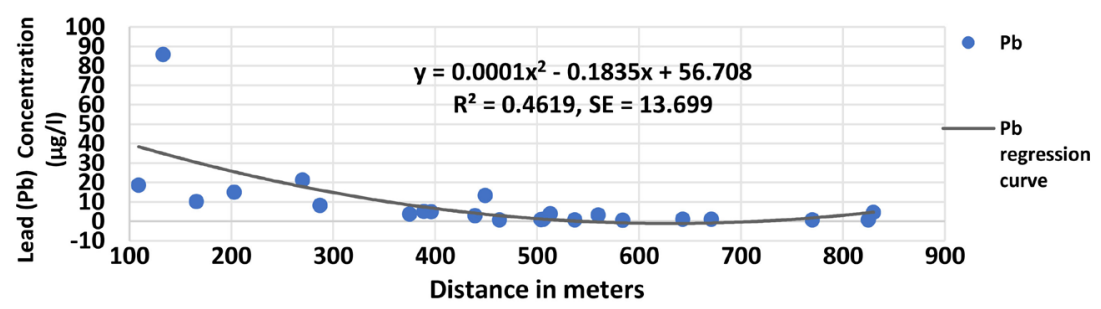

Figure 4. Relationship between the concentration of Lead $(\mathrm{Pb})$ to distance from scrap metal shredder.

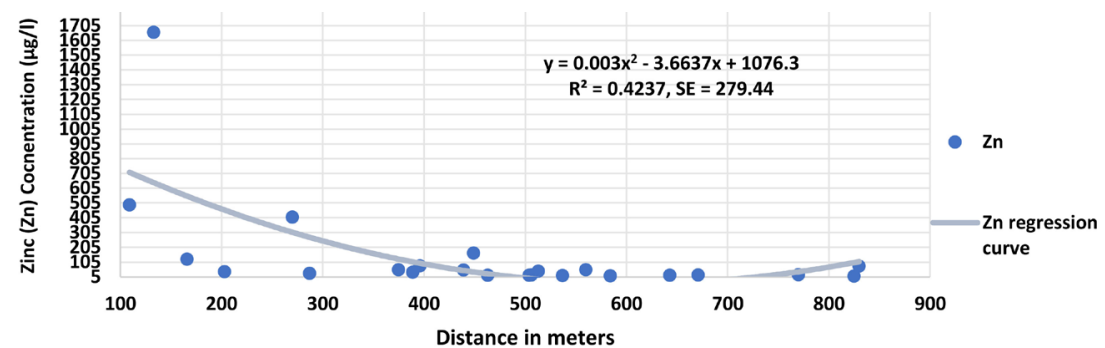

Figure 5. Relationship between Zinc ( $\mathrm{Zn}$ ) concentration in snow versus distance of sample points to the scrap metal shredder.

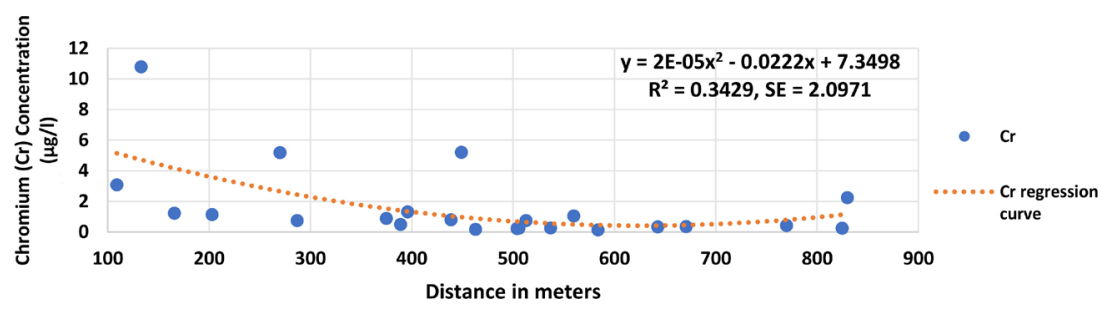

Figure 6. Relationship between Chromium (Cr) concentration in snow versus distance of sample points to the scrap metal shredder.

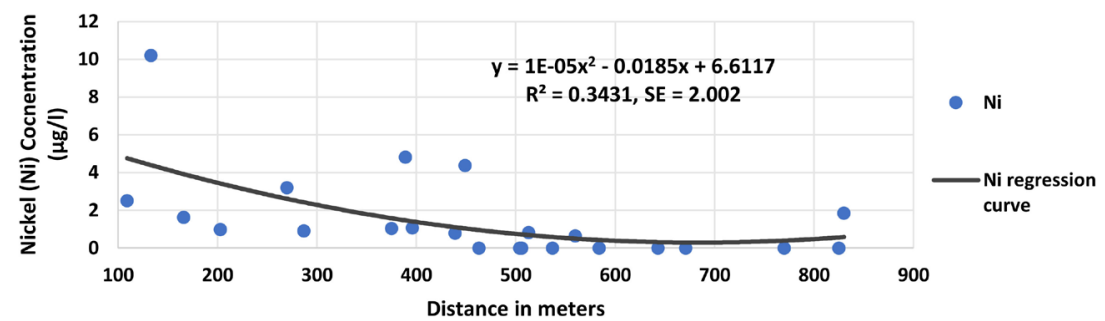

Figure 7. Relationship between Nickel (Ni) concentration in snow and distance of the sample points to the scrap metal shredder. 


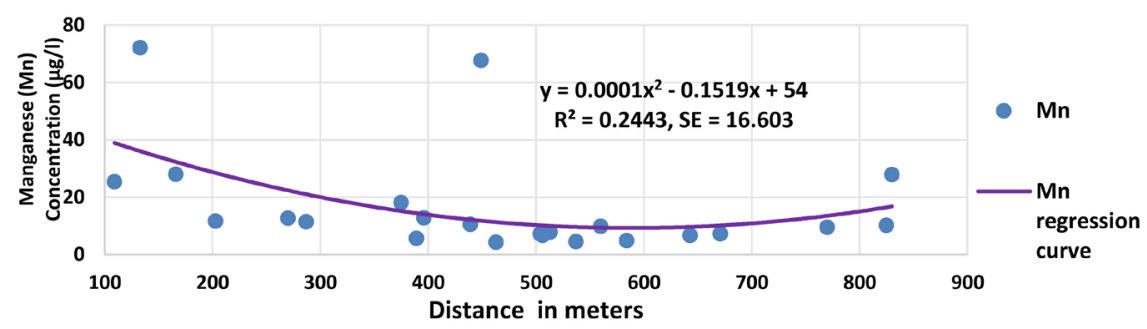

Figure 8. Relationship between Manganese (Mn) concentration in snow and distance of the sample points to the scrap metal shredder.

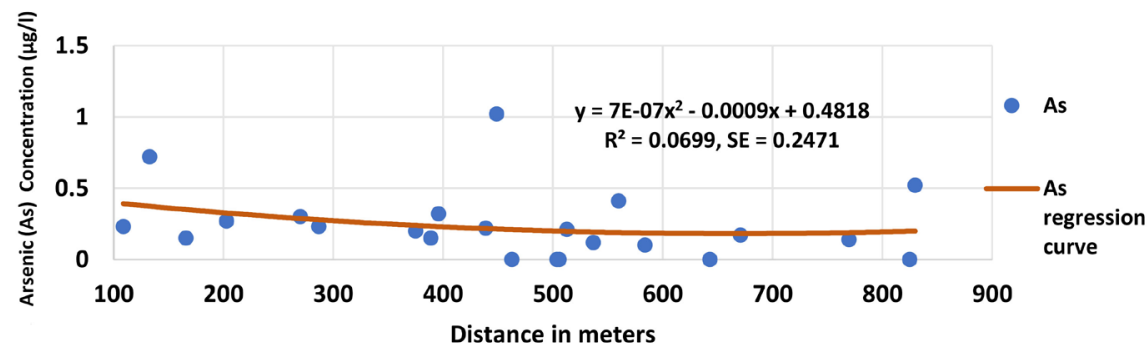

Figure 9. Relationship between the concentration of Arsenic (As) versus distance from scrap metal shredder.

metals were highest at the shredder and diminished with further distance from shredder.

\subsection{Spatial Analysis and Kriging Interpolation of Heavy Metals Distribution}

All eight maps, shown in Figures 10-17, indicate the shredder area is the most contaminated area for all eight heavy metals notably for $\mathrm{Pb}, \mathrm{Zn}, \mathrm{Ni}, \mathrm{Cr}, \mathrm{Cd}$, and $\mathrm{Hg}$, decreasing with the distance from this source to low or moderate levels in residences. Furthermore, Siudek et al. (2015) reported similar high concentrations of $\mathrm{Pb}, \mathrm{Ni}, \mathrm{Zn}$, and $\mathrm{Cr}$ in snow samples downwind from industrial/urban emissions sources. The findings from this map concurred with Ha et al. (2014) interpolated maps of high levels of $\mathrm{Pb}, \mathrm{Cd}$, and $\mathrm{Zn}$ in air emissions from nearby metal foundries. These findings suggest that the scrap metal recycling shredder is the source of heavy metals, which adsorb and deposit on snow surfaces.

Furthermore, the meteorological factor, such as prevailing wind direction plays a significant role in the dispersion and deposition of industrial emission of heavy metals in accumulated snow cover (Krastinyte et al., 2013). Wind speed and direction data were obtained from the meteorological weather station of Environment Canada, The Forks, Winnipeg and shown in Figure 18's wind rose. At the receiving end of the prevailing west/northwest wind direction is the scrap metal shredder, which is located in the northeast direction of our interpolated maps. This prevailing northwest wind may contribute to significant fallout of heavy metal particles in the downwind area, especially the northeast and part of the southeast. 


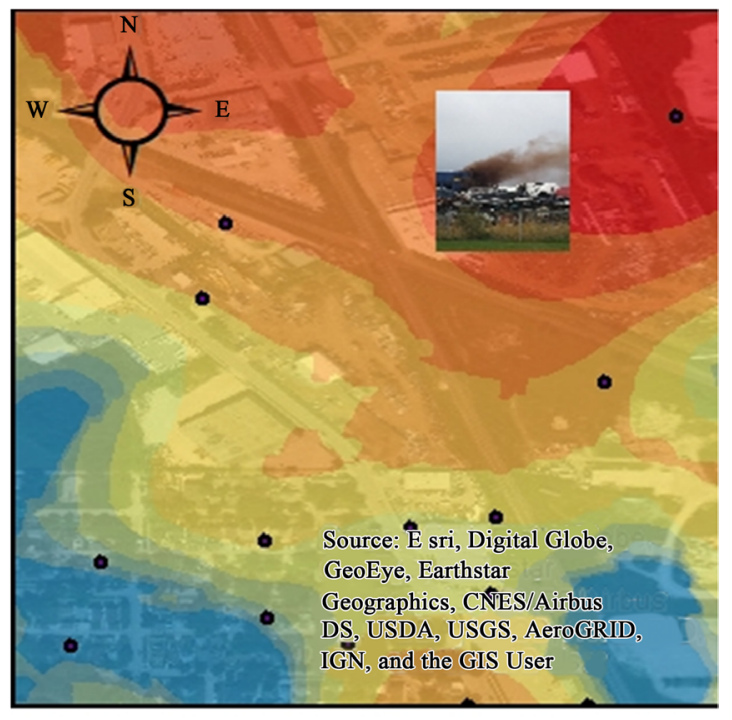

Lead Distribution in Industrial and Residential Snowpack

\begin{tabular}{l|l} 
Lead Concentration $(\mu \mathrm{g} / \mathrm{L})$ & $4.56-8.07$ \\
$0.51-0.69$ & $8.07-14.5$ \\
$0.69-1.00$ & $14.5-26.1$ \\
$1.00-1.58$ & $26.1-47.3$ \\
$1.58-2.64$ & $47.2-85.8$ \\
$2.64-4.56$ &
\end{tabular}

$1 \mathrm{~cm}=0.1 \mathrm{~km}$

Figure 10. Spatial distribution of Lead $(\mathrm{Pb})$ in undisturbed snowpack in South St. Boniface.

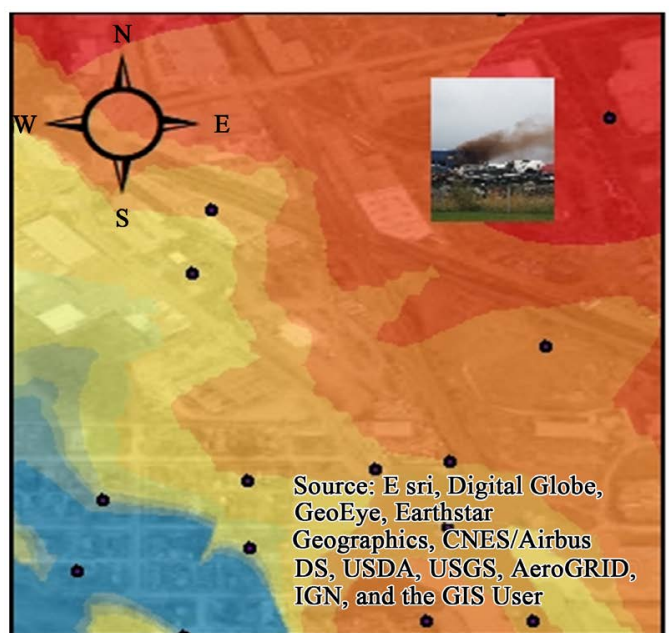

\begin{tabular}{|l|l|}
\hline Zinc Distribution in Industrial and Residential Snowpack \\
Zinc Concentration $(\mu \mathrm{g} / \mathrm{L})$ & $23.1-37.5$ \\
$9.3-14.2$ & $37.5-80.1$ \\
$14.2-15.9$ & $80.1-206$ \\
$15.9-16.5$ & $206-574$ \\
$16.5-18.1$ & $574-1660$ \\
$18.1-23.1$ & \\
\hline $\mathrm{cm}=$ & $0.11 \mathrm{~km}$
\end{tabular}

Figure 11. Spatial distribution of Zinc ( $\mathrm{Zn})$ in undisturbed snowpack in South St. Boniface. 


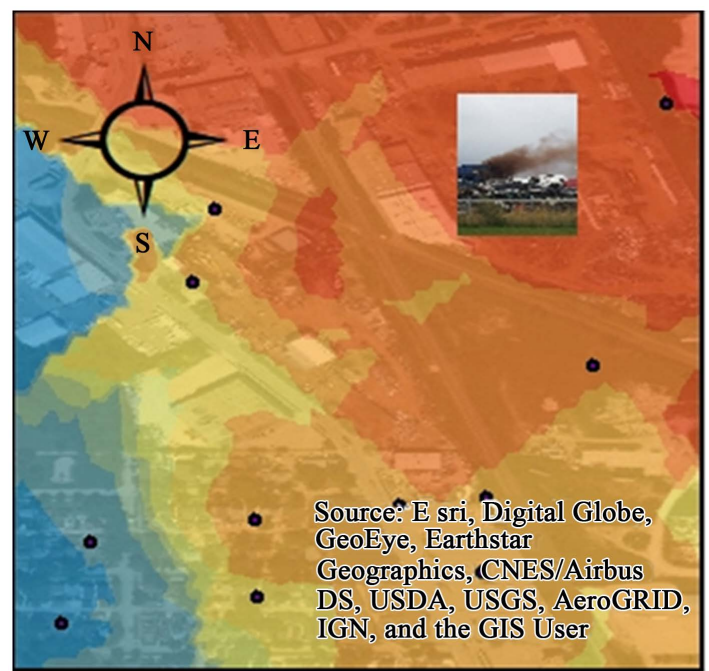

Nickel Distribution in Industrial and Residential Snowpack Nickel Concentrations $(\mu \mathrm{g} / \mathrm{L}) \quad 1.03-1.27$

$0-0.51$

$0.51-0.75$

$1.27-1.78$

$0.75-0.86$

$1.78-2.87$

$0.86-0.92$

$2.87-5.2$

$0.92-1.03$

$1 \mathrm{~cm}=0.1 \mathrm{~km}$

Figure 12. Spatial distribution of Nickel (Ni) in undisturbed snowpack in South St. Boniface.

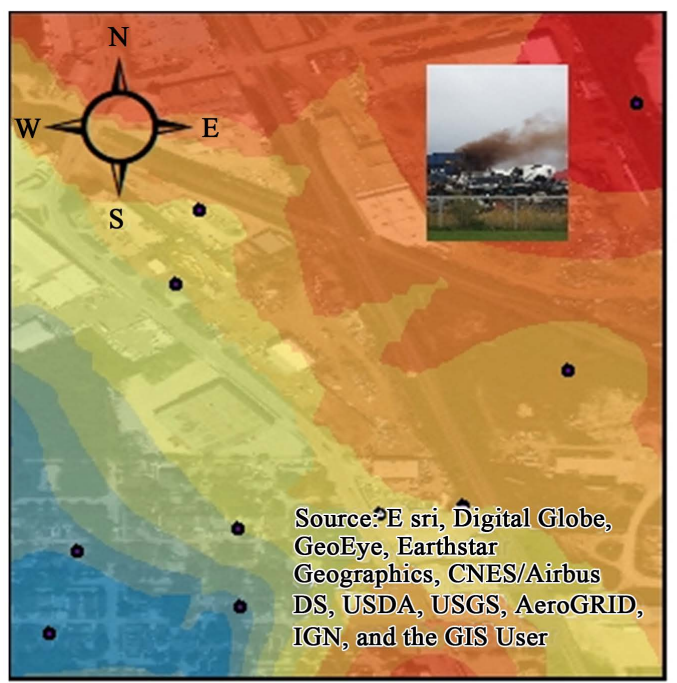

Chromium Distribution in Industrial and Residential Snowpack

Chromium Concentrations $(\mu \mathrm{g} / \mathrm{L})$

$0.14-0.22$

$0.22-0.30$

$0.30-0.35$

$0.35-0.50$

$0.50-0.75$

$1 \mathrm{~cm}=0.1 \mathrm{~km}$

Figure 13. Spatial distribution of Chromium (Cr) in undisturbed snowpack in South St. Boniface. 


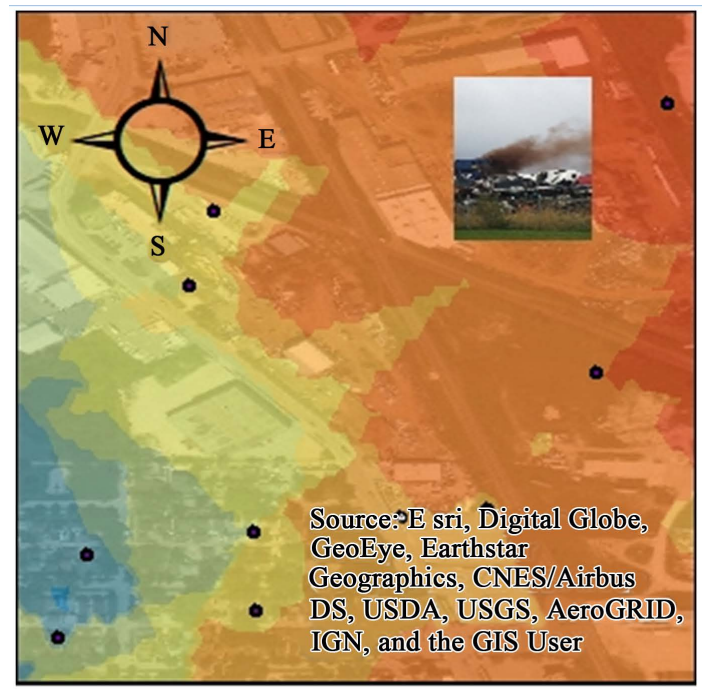

Manganese Distribution in Industrial and Residential Snowpack

\begin{tabular}{|l|l} 
Manganese Concentration $(\mu \mathrm{g} / \mathrm{L})$ & $9.83-12.7$ \\
$4.33-5.93$ & $12.7-17.8$ \\
$5.93-6.83$ & $17.8-26.9$ \\
$6.83-7.33$ & $26.9-43.2$ \\
$7.33-8.23$ & $43.2-72.2$ \\
$8.23-9.83$ &
\end{tabular}

$1 \mathrm{~cm}=0.1 \mathrm{~km}$

Figure 14. Spatial distribution of Manganese (Mn) in undisturbed snowpack in South St. Boniface.

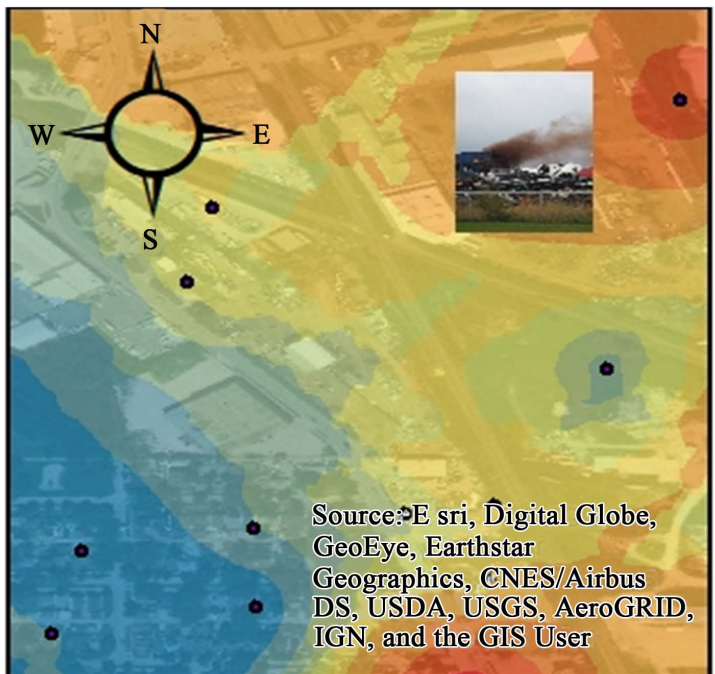

Arsenic Distribution in Industrial and Residential Snowpack

\begin{tabular}{l|l} 
Arsenic Concentrations $(\mu \mathrm{g} / \mathrm{L})$ & $0.25-0.31$ \\
$0-0.09$ & $0.31-0.40$ \\
$0.09-0.15$ & $0.40-0.53$ \\
$0.15-0.19$ & $0.53-0.73$ \\
$0.19-0.21$ & $0.73-1.02$
\end{tabular}

$1 \mathrm{~cm}=0.1 \mathrm{~km}$

Figure 15. Spatial distribution of Arsenic (As) in undisturbed snowpack in South St. Boniface. 


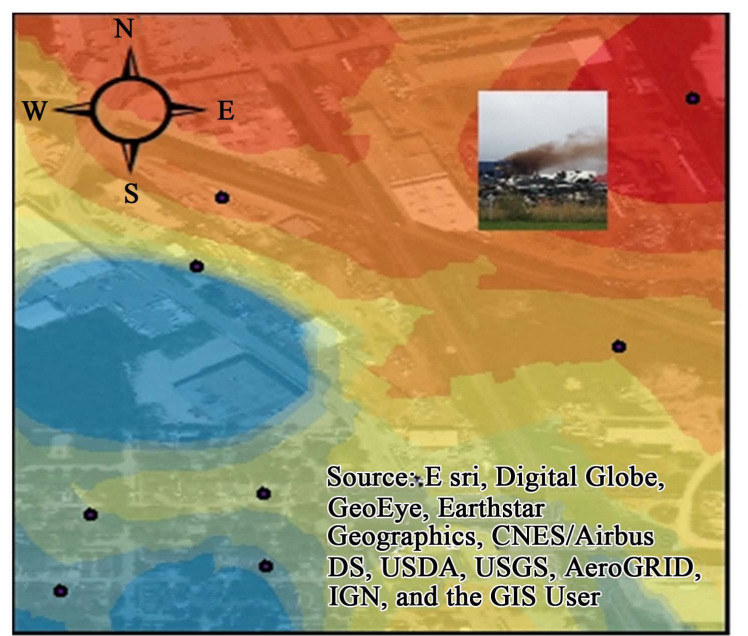

Cadmium Distribution in Industrial and Residential Snowpack

\begin{tabular}{|l|l|}
\hline Cadmium $(\mu \mathrm{g} / \mathrm{L})$ & $0.12-0.20$ \\
$0.01-0.02$ & $0.20-0.32$ \\
$0.02-0.03$ & $0.32-0.54$ \\
\hline $0.03-0.04$ & $0.54-0.91$ \\
\hline $0.04-0.07$ & $0.91-1.53$ \\
\hline $0.07-0.12$ & \\
\hline
\end{tabular}

$1 \mathrm{~cm}=0.1 \mathrm{~km}$

Figure 16. Spatial distribution of Cadmium (Cd) in undisturbed snowpack in South St. Boniface.

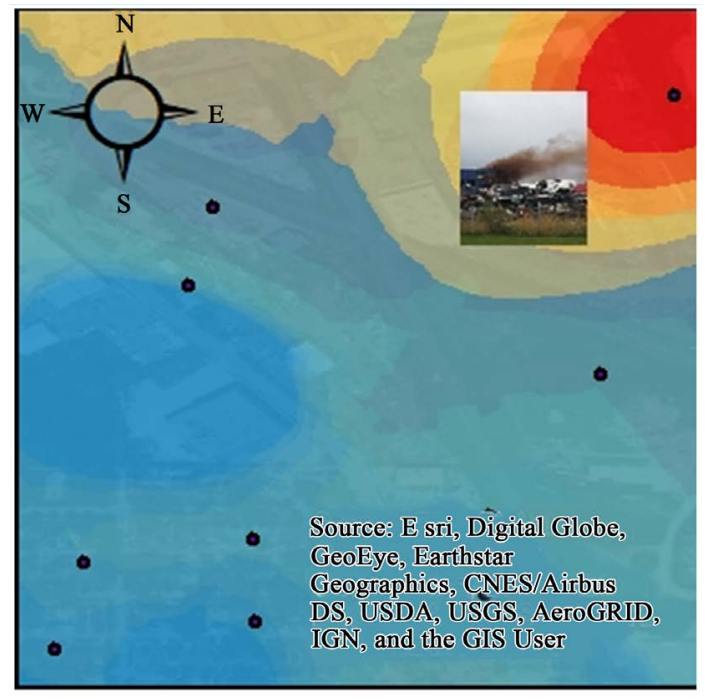

Mercury Distribution in Undisturbed Snowpack

\begin{tabular}{|c|c|}
\hline Mercury $(\mu \mathrm{g} / \mathrm{L})$ & $0.09-0.10$ \\
\hline $0-0.03$ & $0.12-0.16$ \\
$0.03-0.06$ & $0.16-0.20$ \\
$0.06-0.09$ &
\end{tabular}

$1 \mathrm{~cm}=0.1 \mathrm{~km}$

Figure 17. Spatial distribution of Mercury $(\mathrm{Hg})$ in undisturbed snowpack in South St. Boniface. 


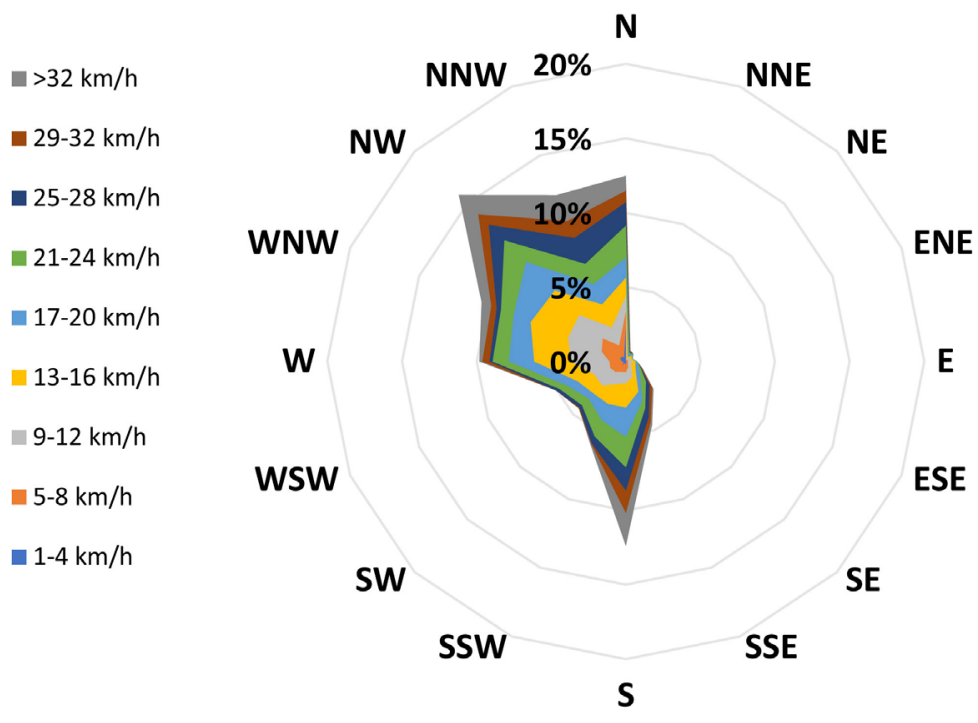

Figure 18. Wind rose for wind speed and wind direction measurement from the forks weather station (Environment Canada), Winnipeg. (1st November 2018 to 13th March 2019).

\section{Conclusion}

This study conducted a spatial analysis of heavy metal concentrations in snow samples. Many different ways to assess and compare heavy metal concentrations at different distances from the shredder and different zones were undertaken. Every analysis pointed to the zone surrounding the shredder as being the most contaminated at the shredder and decreasing with distance from the shredder. Higher concentrations closer to the shredder were significant for every metal, but arsenic, in regression modelling $\mathrm{R}$ squared ( 0.585 for $\mathrm{Cd}, 0.462$ for $\mathrm{Pb}, 0.423$ for $\mathrm{Zn}, 0.343$ for $\mathrm{Cr}, 0.343$ for $\mathrm{Ni}, 0.244$ for $\mathrm{Mn}$, and 0.069 for As). Heavy metals concentrations were found to be significantly higher in the industrial zone, with next highest being the roadside, then the commercial zone and finally the residential/parkland zone, at $\mathrm{p}$-value $<0.01$ statistical significance levels according to the non-parametric Kruskal-Wallis H-test. The spatial analysis of heavy metals concentrations measured in the snow sample sites displays that all toxic metals, particularly $\mathrm{Pb}, \mathrm{Ni}, \mathrm{Zn}, \mathrm{Cr}$, and $\mathrm{Hg}$, have highest concentrations proximate to the scrap metal shredder. Furthermore, different pollution indices, specifically contamination factor (CF), degree of contamination (DOC), and pollution load index (PLI),all registering high contamination. The CF registered high for lead, zinc, and nickel in all areas compared to the background levels with the highest levels nearby a scrap metal shredder. The DOC values showed that the industrial contamination is roughly five times greater than that for the road or commercial areas and almost 20 times more contaminated compared to the residential/parkland. With PLI levels above 1 considered contaminated, the shredder (4.1), roadside (2.2) and commercial areas (1.9) were polluted but not the residential/parkland areas (0.6). These findings point to the scrap metal shredder as causing the present-day contamination for all areas studied, including residential/parkland, traf- 
fic and commercial areas. High levels of toxic metal air pollution proximate to a community warrant further study of human exposure and health risk posed by multiple sources from air, water and land. Enforcement and enclosure of the outdoor shredder should be considered to reduce heavy metal exposure.

\section{Acknowledgements}

We acknowledge and appreciate financial and other supports provided by the South St. Boniface Resident Association, Winnipeg Manitoba, for the data collection and laboratory analysis and SSHRC funding.

\section{Conflicts of Interest}

The authors declare no conflicts of interest regarding the publication of this paper.

\section{References}

Adamiec, E., Jarosz-Krzemińska, E., \& Wieszała, R. (2016). Heavy Metals from Non-Exhaust Vehicle Emissions in Urban and Motorway Road Dusts. Environmental Monitoring and Assessment, 188, 369. https://doi.org/10.1007/s10661-016-5377-1

Agency for Toxic Substance and Disease Registry (ATSDR) (2005). Toxic Substance Profile for Zinc: Public Health Statement.

https://www.atsdr.cdc.gov/phs/phs.asp?id=300\&tid=54

Agency for Toxic Substance and Disease Registry (ATSDR). (2017). Lead Toxicity and What Are Possible Health Effects from Lead Exposure?

https://www.atsdr.cdc.gov/csem/csem.asp?csem $=34 \& p o=10$

Akintuyi, A., Raji A, S., \& Wunude, E. (2014). GIS-Based Assessment and Mapping of Noise Pollution in Bariga Area of Lagos State, Nigeria. Sokoto Journal of the Social Sciences, 4, 154-168. https://www.researchgate.net/publication/275034987

Apanpa-Qasim, A., Adeyi, A., Mudliar, S., Raghunathan, K., \& Thawale, P. (2016). Examination of Lead and Cadmium in Water-Based Paints Marketed in Nigeria. Journal of Health \& Pollution, 6, 43-49. https://doi.org/10.5696/2156-9614-6.12.43

Backman, B., Bodiš, D., Lahermo, P., Rapant, S., \& Tarvainen, T. (1998). Application of a Groundwater Contamination Index in Finland and Slovakia. Environmental Geology, 36, 55-64. https://doi.org/10.1007/s002540050320

Baltrenaite, E., Baltrėnas, P., Lietuvninkas, A., Šerevičienė, V., \& Zuokaite, E. (2014). Integrated Evaluation of Aerogenic Pollution by Air-Transported Heavy Metals ( $\mathrm{Pb}, \mathrm{Cd}$, $\mathrm{Ni}, \mathrm{Zn}, \mathrm{Mn}$ and $\mathrm{Cu}$ ) in the Analysis of the Main Deposit Media. Environmental Science and Pollution Research, 21, 299-313. https://doi.org/10.1007/s11356-013-2046-6

Barbante, C., Boutron, C., Morel, C., Ferrari, C., Jaffrezo, J., Cozzi, G., \& Cescon, P. (2003). Seasonal Variations of Heavy Metals in Central Greenland Snow Deposited from 1991 to 1995. Journal of Environmental Monitoring, 5, 328-335.

https://doi.org/10.1039/b210460a

Brown, J. S., Gordon, T., Price, O., \& Asgharian, B. (2013). Thoracic and Respirable Particle Definitions for Human Health Risk Assessment. Particle and Fibre Toxicology, 10, 12. https://doi.org/10.1186/1743-8977-10-12

Carling, G., Fernandez, D., \& Johnson, W. (2012). Dust-Mediated Loading of Trace and Major Elements to Wasatch Mountain Snowpack. Science of the Total Environment, 432, 65-77. https://doi.org/10.1016/j.scitotenv.2012.05.077 
Centre for Disease Control (CDC) (2018). Lead: Health Problems Caused by Lead. https://www.cdc.gov/niosh/topics/lead/health.html

Cereceda-Balic, F., Palomo-Marin, M. R., Bernalte, E., Vidal, V., Christie, J., Fadic, X., Guevara, J. L., Miro, C., \& Pinilla, G. (2012). Impact of Santiago de Chile Urban Atmospheric Pollution on Anthropogenic Trace Elements Enrichment in Snow Precipitation at Cerro Colorado, Central Andes. Atmospheric Environment, 47, 51-57.

https://doi.org/10.1016/j.atmosenv.2011.11.045

City of Winnipeg (2019). 2016 Census Data-St. Boniface Community Area. https://www.winnipeg.ca/census/2016/Community\%20Area/St.\%20Boniface\%20Com munity\%20Area/St.\%20Boniface\%20Community\%20Area.pdf

Claus Henn, B., Ettinger, A. S., Schwartz, J., Téllez-Rojo, M. M., Lamadrid-Figueroa, H., Hernández-Avila, M., Schnaas, L., Amarasiriwardena, C., Bellinger, D. C., Hu, H., \& Wright, R. O. (2010). Early Postnatal Blood Manganese Levels and Children's Neurodevelopment. Epidemiology, 21, 433-439. https://doi.org/10.1097/EDE.0b013e3181df8e52

Darnton-Hill, I. (2013). Zinc Supplementation and Growth in Children. World Health Organization e-Library of Evidence for Nutrition Actions (eLENA). https://www.who.int/elena/bbc/zinc_stunting/en/

Douglas, T., \& Sturm, M. (2004). Arctic Haze, Mercury and the Chemical Composition of Snow across Northwestern Alaska. Atmospheric Environment, 38, 805-820. https://doi.org/10.1016/j.atmosenv.2003.10.042

Elik, A. (2002). Monitoring of Heavy Metals in Urban Snow as Indicator of Atmosphere Pollution. International Journal of Environmental Analytical Chemistry, 82, 37-45. https://doi.org/10.1080/03067310290024085

Engelhard, C., De Toffol, S., Lek, I., Rauch, W., \& Dallinger, R. (2007). Environmental Impacts of Urban Snow Management-The Alpine Case Study of Innsbruck. Science of the Total Environment, 382, 286-294. https://doi.org/10.1016/j.scitotenv.2007.04.008

Gabrielli, P., Cozzi, G., Torcini, S., Cescon, P., \& Barbante, C. (2006). Source and Origin of Atmospheric Trace Elements Entrapped in Winter Snow of The Italian Eastern Alps. Atmospheric Chemistry and Physics Discussions, 6, 8781-8815.

https://hal.archives-ouvertes.fr/hal-00302116 https://doi.org/10.5194/acpd-6-8781-2006

Government of Canada (2015). Chromium in Drinking Water: Application of the Guideline and Monitoring.

https://www.canada.ca/en/health-canada/programs/chromium-drinking-water/chromi um-drinking-water.html

Grannas, A. M. (2014). Encyclopedia of Snow, Ice and Glaciers (pp. 138-139). Berlin: Springer.

Ha, H., Olson, J., Bian, L., \& Rogerson, P. (2014). Analysis of Heavy Metal Sources in Soil Using Kriging Interpolation on Principal Components. Environmental Science \& Technology, 48, 4999-5007. https://doi.org/10.1021/es405083f

Hakanson, L. (1980). An Ecological Risk Index for Aquatic Pollution Control a Sedimentological Approach. Water Research, 14, 975-1001. https://doi.org/10.1016/0043-1354(80)90143-8

Host, S., Larrieu, S., Pascal, L., Blanchard, M., Declercq, C., Fabre, P., \& Lefranc, A. (2008). Short-Term Associations between Fine and Coarse Particles and Hospital Admissions for Cardiorespiratory Diseases in Six French Cities. Occupational and Environmental Medicine, 65, 544-551. https://doi.org/10.1136/oem.2007.036194

Industrial Metals Annual Report (IMAR) (2017). Public File Registry: Industrial Metal 
Scrap Shredding Facility. http://gov.mb.ca/sd/eal/registries/5344industrial/index.html

International Agency for Research on Cancer (IARC) (2020). Iarc Monographs on the Identification of Carcinogenic Hazards to Humans (Volumes 1-125). Agents classified by the IARC Monographs. https://monographs.iarc.fr/list-of-classifications

International Labour Organization (ILO) (2004). Promoting Jobs and Protecting People: Metals.

http://www.ilo.org/legacy/english/protection/safework/cis/products/safetytm/metals.htm

Khalid, N., Hussain, M., Young, H., Boyce, B., Aqeel, M., \& Noman, A. (2018). Effects of Road Proximity on Heavy Metal Concentrations in Soils and Common Roadside Plants in Southern California. Environmental Science and Pollution Research, 25, 3525735265. https://doi.org/10.1007/s11356-018-3218-1

Krastinyte, V., Baltrènaite, E., \& Lietuvninkas, A. (2013). Analysis of Snow-Cap Pollution for Air Quality Assessment in the Vicinity of an Oil Refinery. Environmental Technology, 34, 757-763. https://doi.org/10.1080/09593330.2012.715758

Lancaster, V., \& Keller-Mcnulty, S. (1998). A Review of Composite Sampling Methods. Journal of the American Statistical Association, 93, 1216-1230.

https://doi.org/10.1080/01621459.1998.10473781

Lenntech (2020). Chemical Properties of Nickel: Health Effects of Nickel and Environmental Effects of Nickel. https://www.lenntech.com/periodic/elements/ni.htm

Li, K., Liang, T., \& Wang, L. (2016). Risk Assessment of Atmospheric Heavy Metals Exposure in Baotou, a Typical Industrial City in Northern China. Environmental Geochemistry and Health, 38, 843-853. https://doi.org/10.1007/s10653-015-9765-1

Loranger, S., Tétrault, M., Kennedy, G., \& Zayed, J. (1996). Manganese and Other Trace Elements in Urban Snow Near an Expressway. Environmental Pollution, 92, 203-211. https://doi.org/10.1016/0269-7491(95)00082-8

Loren, R., Karl, P., Daniel, H., Donald, R., Arturo, B., \& Jiao, L. (2013). Unanticipated Potential Cancer Risk Near Metal Recycling Facilities. Journal of Environmental Impact Assessment Review, 41, 70-77. https://doi.org/10.1016/j.eiar.2013.03.001

McGrath, D., Zhang, C., \& Carton, O. (2004). Geostatistical Analyses and Hazard Assessment on Soil Lead in Silvermines Area, Ireland. Environmental Pollution, 127, 239-248. https://doi.org/10.1016/j.envpol.2003.07.002

Nakajima, F., \& Aryal, R. (2018). Heavy Metals in Urban Dust, Heavy Metals. London: IntechOpen. https://doi.org/10.5772/intechopen.74205

https://www.intechopen.com/books/heavy-metals/heavy-metals-in-urban-dust

Nazarenko, Y., Kurien, U., Nepotchatykh, O., Rangel-Alvarado, R., \& Ariya, P. (2016). Role of Snow and Cold Environment in the Fate and Effects of Nanoparticles and Select Organic Pollutants from Gasoline Engine Exhaust. Journal of Environmental Monitoring, 18, 190-199. https://doi.org/10.1039/C5EM00616C

Nordqvist, J. (2017). What Are the Health Benefits of Zinc? https://www.medicalnewstoday.com/articles/263176

Occupational Safety and Health Administration (OSHA) (2008). Guidance for the Identification and Control of Safety and Health Hazards in Metal Scrap Recycling. https://www.osha.gov/Publications/OSHA3348-metal-scrap-recycling.pdf

Ogundele, L., Owoade, O., Hopke, P., \& Olise, F. (2017). Heavy Metals in Industrially Emitted Particulate Matter in Ile-Ife, Nigeria. Environmental Research, 156, 320-325. https://doi.org/10.1016/j.envres.2017.03.051

Ogundele, L., Owoade, O., Olise, F., \& Hopke, P. (2016). Source Identification and Apportionment of $\mathrm{PM}_{2.5}$ and $\mathrm{PM}_{2.5-10}$ in Iron and Steel Scrap Smelting Factory Environ- 
ment Using PMF, PCFA and UNMIX Receptor Models. Environmental Monitoring and Assessment, 188, 1-21. https://doi.org/10.1007/s10661-016-5585-8

Olawoyin, R., Schweitzer, L., Zhang, K., Okareh, O., \& Slates, K. (2018). Index Analysis and Human Health Risk Model Application for Evaluating Ambient Air-Heavy Metal Contamination in Chemical Valley Sarnia. Ecotoxicology and Environmental Safety, 148, 72-81. https://doi.org/10.1016/j.ecoenv.2017.09.069

Owoade, K., Hopke, P., Olise, F., Ogundele, L., Fawole, O., Olaniyi, B., \& Bashiru, M. (2015). Chemical Compositions and Source Identification of Particulate Matter $\left(\mathrm{PM}_{2.5}\right.$ and $\mathrm{PM}_{2.5-10}$ ) from a Scrap Iron and Steel Smelting Industry along the Ife-Ibadan Highway, Nigeria. Atmospheric Pollution Research, 6, 107-119.

https://doi.org/10.5094/APR.2015.013

Oyedepo, S. O., Adeyemi, G. A., Olawole, O. C., Ohijeagbon, O. I., Fagbemi, O. K. et al. (2019). A GIS-Based Method for Assessment and Mapping of Noise Pollution in Ota Metropolis, Nigeria. Methods X, 6, 447-457. https://doi.org/10.1016/j.mex.2019.02.027

Phillips, S., Wotton, D., \& McEachern, D. (1986). Snow Chemistry in the Flin Flon Area of Manitoba, 1981-1984. Water, Air, and Soil Pollution, 30, 253-261. https://doi.org/10.1007/BF00305196

Pobi, K., Satpati, S., Dutta, S., Nayek, S., Saha, R., \& Gupta, S. (2019). Sources Evaluation and Ecological Risk Assessment of Heavy Metals Accumulated Within a Natural Stream of Durgapur Industrial Zone, India, by Using Multivariate Analysis and Pollution Indices. Applied Water Science, 9, 1-16.

https://doi.org/10.1007/s13201-019-0946-4

Raaschou-Nielsen, O., Andersen, Z., Beelen, R., Samoli, E., Stafoggia, M., Weinmayr, G., $\&$ Nafstad, P. (2013). Air Pollution and Lung Cancer Incidence in 17 European Cohorts: Prospective Analyses from the European Study of Cohorts for Air Pollution Effects (ESCAPE). Lancet Oncology, 14, 813-822.

https://doi.org/10.1016/S1470-2045(13)70279-1

Ridgway, J., \& Shimmield, G. (2002). Estuaries as Repositories of Historical Contamination and Their Impact on Shelf Seas. Estuarine, Coastal and Shelf Science, 55, 903-928. https://doi.org/10.1006/ecss.2002.1035

Sakai, H., Sasaki, T., \& Saito, K. (1988). Heavy Metal Concentrations in Urban Snow as an Indicator of Air Pollution. Science of the Total Environment, 77, 163-174. https://doi.org/10.1016/0048-9697(88)90053-8

Salas-Luevano, M., \& Vega-Carrillo, H. (2016). Environmental Impact in a Rural Community Due to a Lead Recycling Plant in Zacatecas, Mexico. Environmental Earth Sciences, 75, 1-9. https://doi.org/10.1007/s12665-016-5247-8

Sanders, T., Liu, Y., Buchner, V., \& Tchounwou, P. B. (2009). Neurotoxic Effects and Biomarkers of Lead Exposure: A Review. Reviews on Environmental Health, 24, 15-45. https://doi.org/10.1515/REVEH.2009.24.1.15

Shen, F., Mao, L., Sun, R., Du, J., Tan, Z., \& Ding, M. (2019). Contamination Evaluation and Source Identification of Heavy Metals in the Sediments from the Lishui River Watershed, Southern China. International Journal of Environmental Research and Public Health, 16, 336. https://doi.org/10.3390/ijerph16030336

Siudek, P., Frankowski, M., \& Siepak, J. (2015). Trace Element Distribution in The Snow Cover from an Urban Area in Central Poland. Environmental Monitoring and Assessment, 187, 225. https://doi.org/10.1007/s10661-015-4446-1

Smolders, E., \& Degryse, F. (2002). Fate and Effect of Zinc from Tire Debris in Soil. Environmental Science \& Technology, 36, 3706-3710.

https://doi.org/10.1021/es025567p 
Soriano, A., Pallarés, S., Pardo, F., Vicente, A., Sanfeliu, T., \& Bech, J. (2012). Deposition of Heavy Metals from Particulate Settleable Matter in Soils of an Industrialised Area. Journal of Geochemical Exploration, 113, 36-44. https://doi.org/10.1016/j.gexplo.2011.03.006

Tchepel, O., Costa, A., Martins, H., Ferreira, J., Monteiro, A., Miranda, A., \& Borrego, C. (2010). Determination of Background Concentrations for Air Quality Models Using Spectral Analysis and Filtering of Monitoring Data. Atmospheric Environment, 44, 106-114. https://doi.org/10.1016/j.atmosenv.2009.08.038

Tchounwou, P. B., Yedjou, C. G., Patlolla, A. K., \& Sutton, D. J. (2012). Heavy Metal Toxicity and the Environment. Experientia Supplementum, 101, 133-164. https://doi.org/10.1007/978-3-7643-8340-4_6

Tolcin, A. (2015). Zinc Statistics and Information. National Information Center, United States Geological Survey.

Tomlinson, D., Wilson, J., Harris, C., \& Jeffrey, D. (1980). Problems in the Assessment of Heavy-Metal Levels in Estuaries and the Formation of a Pollution Index. Helgoländer Meeresuntersuchungen, 33, 566-575. https://doi.org/10.1007/BF02414780

United State Environmental Protection Agency (USEPA) (2009). Assessing the Management of Lead in Scrap Metal and Electric Arc Furnace Dust. U.S. Environmental Protection Agency Office of Resource Conservation and Recovery.

https://archive.epa.gov/epawaste/hazard/wastemin/web/pdf/lead-2.pdf

United State Environmental Protection Agency (USEPA) (2018). Health Effects of PArticulte Matter (PM).

https://www.epa.gov/pm-pollution/health-and-environmental-effects-particulate-matt $\underline{\text { er-pm }}$

Vasić, M.V., Mihailović, A., Kozmidis-Luburić, U., Nemes, T., Ninkov, J., ZeremskiŠkorić, T., \& Antić B. (2012). Metal Contamination of Short-Term Snow Cover Near Urban Crossroad: Correlation Analysis of Metal Content and Fine Particles Distribution. Chemosphere, 86, 585-592. https://doi.org/10.1016/j.chemosphere.2011.10.023

Wernick, I., \& Themelis, N. (1998). Recycling Metals for the Environment. Annual Review of Energy and the Environment, 23, 465-497.

https://doi.org/10.1146/annurev.energy.23.1.465

World Health Organization (2019a). Lead Poisning and Health: Key Facts. https://www.who.int/news-room/fact-sheets/detail/lead-poisoning-and-health

World Health Organization (2019b). Exposure to Lead: A Major Public Health Concern. https://www.who.int/ipcs/features/lead..pdf

Yang, Y., Mei, Y., Zhang, C., Zhang, R., Liao, X., \& Liu, Y. (2016). Heavy Metal Contamination in Surface Soils of the Industrial District of Wuhan, China. Human and Ecological Risk Assessment: An International Journal, 22, 126-140. https://doi.org/10.1080/10807039.2015.1056291

Zhitkovich, A. (2011). Chromium in Drinking Water: Sources, Metabolism, and Cancer Risks. Chemical Research in Toxicology, 24, 1617-1629.

https://doi.org/10.1021/tx200251t 